\title{
1h. 3014
}

MASTER

Nuclear Engineering

Enrollments and Degrees, 1978

Enrollments - Fall 1978

Degrees Granted

July 1966-June 1978

August 1979

\section{U.S. Department of Energy}

Assistant Secretary for Intergovernmental

and Institutional Relations

Division of Labor Affairs

and Manpower Assessment

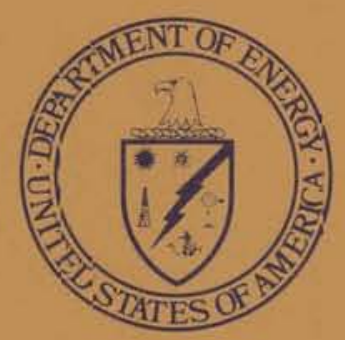




\section{DISCLAIMER}

This report was prepared as an account of work sponsored by an agency of the United States Government. Neither the United States Government nor any agency Thereof, nor any of their employees, makes any warranty, express or implied, or assumes any legal liability or responsibility for the accuracy, completeness, or usefulness of any information, apparatus, product, or process disclosed, or represents that its use would not infringe privately owned rights. Reference herein to any specific commercial product, process, or service by trade name, trademark, manufacturer, or otherwise does not necessarily constitute or imply its endorsement, recommendation, or favoring by the United States Government or any agency thereof. The views and opinions of authors expressed herein do not necessarily state or reflect those of the United States Government or any agency thereof. 


\section{DISCLAIMER}

Portions of this document may be illegible in electronic image products. Images are produced from the best available original document. 
Available from:

National Technical Information Service (NTIS)

U.S. Department of Commerce

5285 Port Royal Road.

Springfield, Virginia 22161

Frice: Printed copy: $\$ 5.25$

Microfiche: $\quad \$ 3.00$

For sale by the Superintendent of Documents, U.S, Government Printing Offre Washington, D.C. 20402

Stock Number 061-000-00335-5 


\section{Nuclear Engineering Enrollment and Degrees, 1978 * 3 Enrollments, † Fall 1978; Degrees Granted, July 1966-June 1978 . August 1979}

\section{U.S. Department of Energy}

Assistant Secretary for Intergovernmental and Institutional Relations Division of Labor Affairs and Manpower Assessment Washington, D.C. 20585

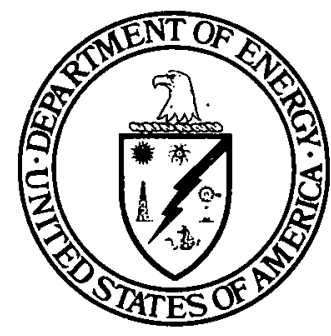

$$
\begin{aligned}
& \text { This report was prepared as an account of work } \\
& \text { sponsored by the United States Government. Neither the } \\
& \text { United States nor the United States Department of } \\
& \text { Energy, noz any of their employees, nor any of their } \\
& \text { contractors, subcontractors, or their employees, makes } \\
& \text { any warranty, express of implied, or assumes any legal } \\
& \text { liability or responsibility for the accuracy, completeness } \\
& \text { or usefulness of any information, apparatus, product or } \\
& \text { process disclosed, or represents that its use would not } \\
& \text { infringe privately owned rights. }
\end{aligned}
$$




\section{FOREWORD}

The present uncertainties concerning nuclear power development could have substantial impacts on the nuclear engineering labor force.

For two decades nuclear power plants have been operating in the United States. At the beginning of 1979 , the number of operating nuclear power plants approached 70 . An additional 70 nuclear power plants are under construction and formal plans exist for over 50 more to become operational over the next 15 years.

Over the past few years there have been significant perturbations in the supply of new engineers with nuclear expertise caused by many factors, such as the general decline in engineering enrollments, concern about involvement in nuclear activities, and uncertainty about a nuclear power future. This series of nuclear engineering enroliment and degree surveys has charted the changes in the supply of professional nuclear personnel and assisted planners and educators alike in preparing to provide for this needed energy resource.

The Department of Energy appreciates the continuing cooperation of the educational institutions involved in nuclear-related engineering training. We acknowledge and thank all those who have provided the data for these reports. 


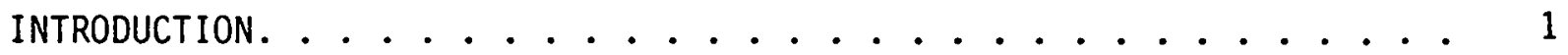

HIGHLIGHTS. ..................... 3

ENROLLMENTS AND DEGREES ....................... 6

Doctorates ...................... 6

Masters. ........................ 6

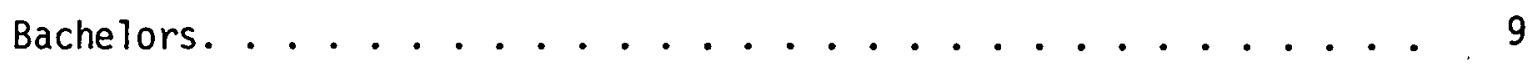

PlACEMENT OF GRADUATES. ........................ 10

WOMEN AND MINORITIES. ....................... 10

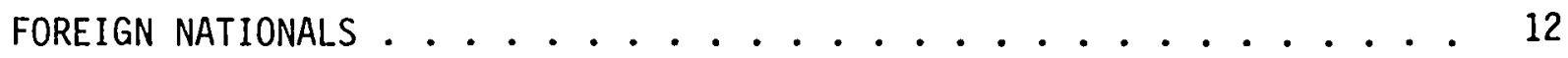

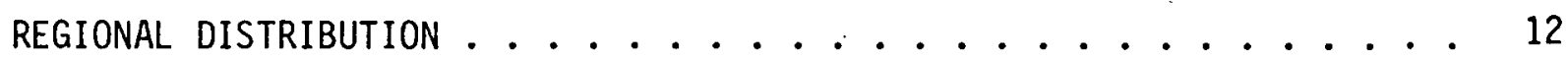
CHARTS :

1. Degrees Granted in Nuclear Engineering, 1966-1978. . . . . . 2

\section{TEXT TABLES :}

1. Enrollment of. Full-time and Part-time Students in Nuclear Engineering by Educational Level (Fall 1972 through Fall 1978) . 5

2. Nuclear Engineering Degrees as a Percentage of all Engineering Degrees by Degree Level, 1967-1978......... 7

3. Undergraduate, Master's, and Doctorate Enroliments and Degrees Granted in Nuclear Engineering or Other Engineering Fields with Nuclear Option, 1975-1978 ............ 8

4. Placement of 1977-78 Nuclear Engineering Graduates by Degree Level. . . . . . . . . . . . . 11

5. Participation by Foreign Nationals, Women, and Minorities in Nuclear Engineering Programs, 1973-1978 ........ 
TABLE OF CONTENTS (Continued)

Page

APPENDICES:

Appendix A. Statistical Tables............. 15

A-1 Degrees Granted 1968-1978 by Institution. . . . . . . 16

A-2 Enrollments and Degrees in Subfields by Institutions. ..............." 21

A-3 Number of Degrees and Enroliments by Subfield

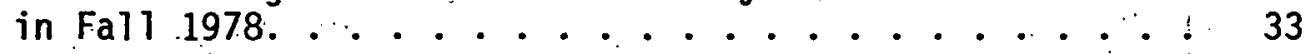

A-4 Minorities, Women, and Foreign Nationals. . . . . . 34

A-5 Nuclear Engineering Curriculum or Options by Undergraduate or Graduate Institution, Fall 1978. . . . 446

A-6 Number of Enrollments and Degrees: by State and Region...................... 52

Appendix B. Addresses . . . . . . . . . . . 55

B-1 Addresses of Institutions in Survey Universe with Active Programs .............. 55

B-2. Addresses of Institutions in Survey Universe with Inactive or Discontinued Programs . . . . . . . 59

Appendix C. Survey Materials.............. 60 


\section{INTRODUCTION}

This report presents the results of the eighth annual survey of Nuclear Engineering Enrollments and Degrees. Each year the survey is sent to institutions offering degrees in nuclear engineering or other engineering disciplines with nuclear engineering options. The number of institutions included may vary from one year to the next as new programs are identified and other programs are discontinued. However, historical information about degrees granted since July 1966 has been collected for all institutions. In this current survey one new. respondent was added (Worcester Polytechnic Institute) that reported enrollments and degrees in nuclear engineering option programs.

For the first time, in Appendix B, addresses of institutions in the survey universe have been separated into active, inactive, or discontinued programs. 


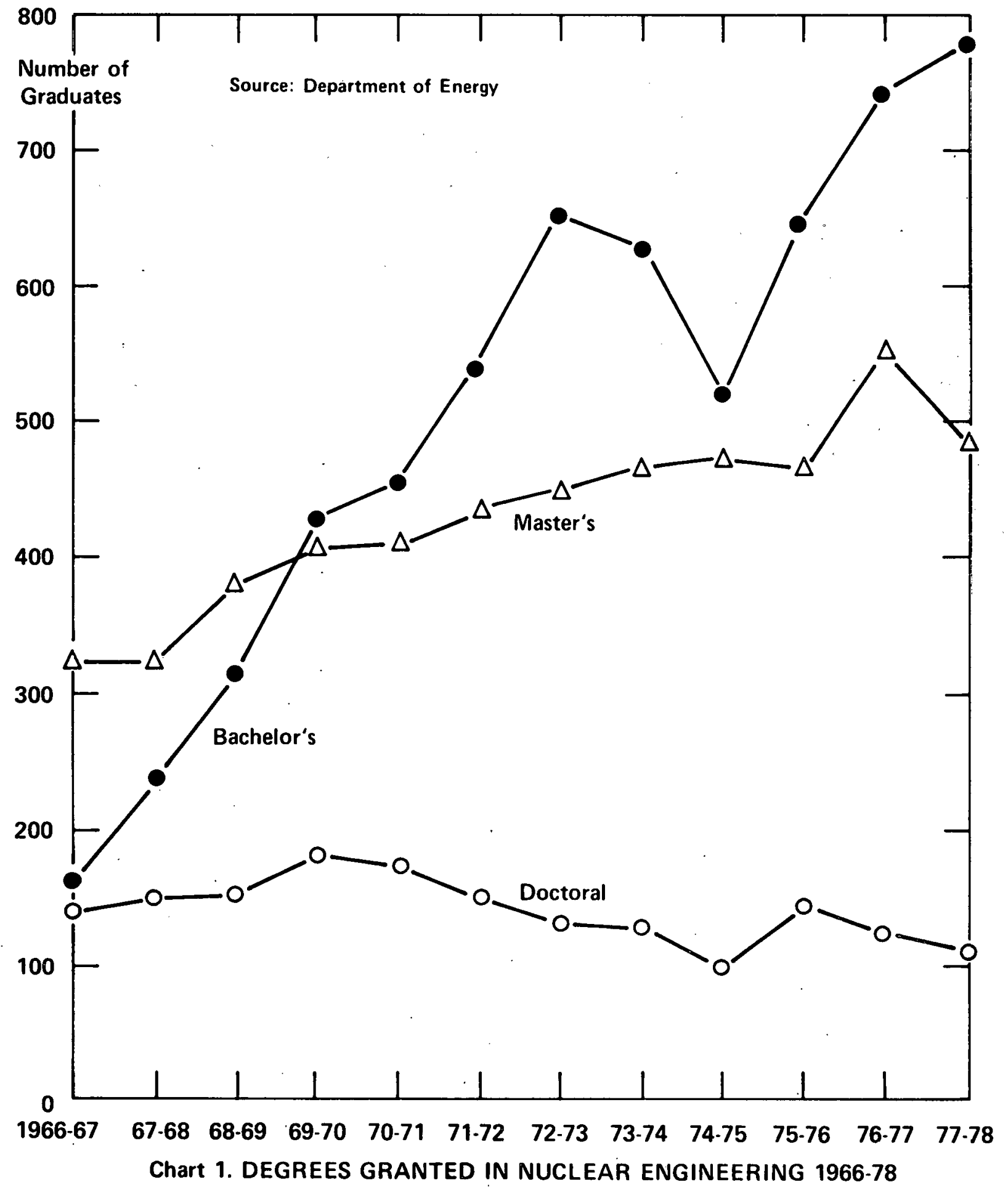




\section{HIGHLIGHTS}

SUR'VEY UNIVERSE:

This survey includes current data on 70 institutions which reported degrees and/or enrollments. One institution was added to the universe, six schools reported no students during this survey year, and two institutions have discontinued their nuclear engineering program.

\section{ENROLLMENT:}

Overall undergraduate enrollment decreased by four percent during 1977-78, with the largest percentage decrease in third year students. Master's enrollment also declined for the third year, but doctoral candidates increased slightly.

\section{DEGREES AWARDED:}

Bachelor degree recipients increased for the third year to a record 777. The number of master's degrees awarded decreased by 67 to 487 after an increase in 1976-77, and the number of doctorate degrees awarded decreased for the second year, to 110 .

\section{PLACEMENT:}

The largest number of degree recipients ever, 394, were placed in industry during 1977-78. Bachelor degree holders represented over half of those finding employment in private industry.

The second largest category, at both the bachelor and master level, were those choosing further study. At the doctorate level, the second largest group of degree recipients chose employment in Government-owned contractor-operated installations. As in 1976-77, very few degree holders (one percent of bachelors and doctorates, less than one percent of masters) were still seeking employment. However, the number of graduates whose placement was unknown increased significantly. 
MINORITIES AND WOMEN:

Minority group (excluding foreign nationals) participation appears to be holding steady at a very low percentage of the total. However, the participation of women continued to increase at some levels.

FOREIGN NATIONALS:

Participation of foreign nationals at the undergraduate level has decreased, but has increased considerably at the graduate levels. Thirty-seven percent of all doctorates and 26 percent of master's degrees were awarded to foreign nationals. Half the Ph.D. candidates were foreign nationals.

REGIONAL DISTRIBUTION:

Undergraduate (22 percent) and graduate (24 percent) enrollment was highest in the East North-Central region. By state, New York awarded the largest number of bachelor's degrees, and Massachusetts granted the largest number of master's and doctoral degrees.

4 
TABLE 1

Enrollment of Full-time and Part-time Students

in Nuclear Engineering by Educational Level

(Fall 1972 through Fall 1978)

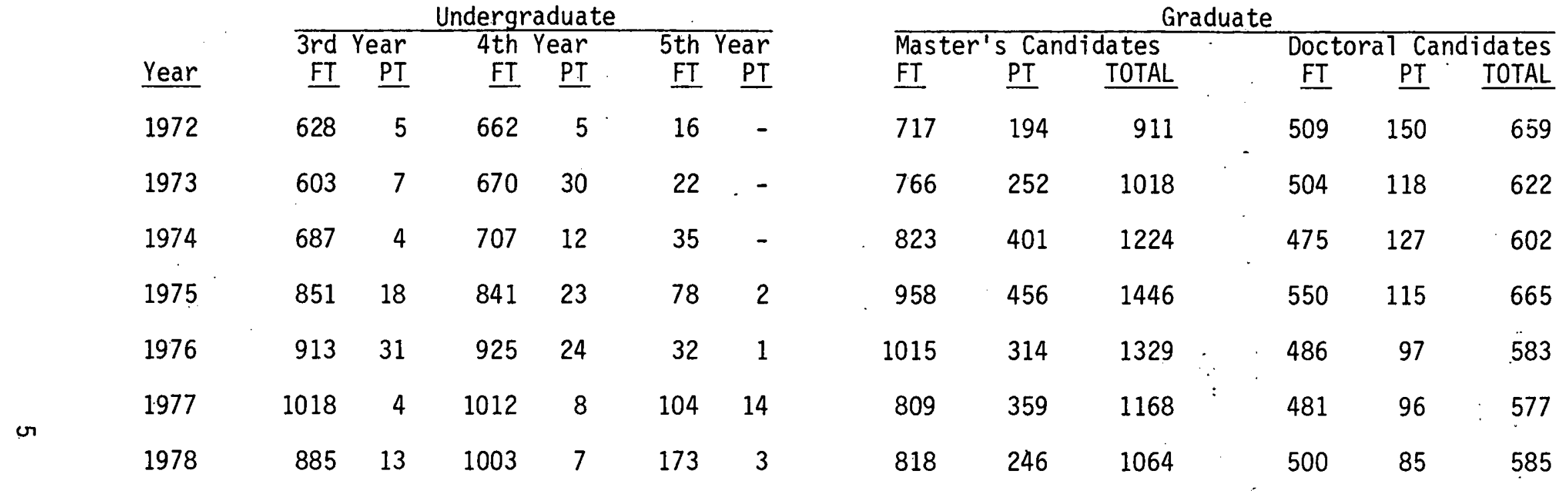

SOURCE: AEC, DNET, Nuclear Engineering Enrollment and Degree Survey, WASH-1228(73), May 1973; AEC, DLR, Nuclear Engineering Enrollments and Degrees, WASH-1228(74), Ju7y 1974; ERDA, DLR, Nuclear Engineering Enrollments and Degrees, ERDA-76(75), September 1975; ERDA, OUP, Nuclear Engineering Enrollments and Degrees, 1975, ERDA-76-102, July 1976; DOE, IR, DLAMA, Nuclear Engineering Enrollments and Degrees, 1977, DOE/IR-0011, 1977; 1978, Department of Energy. 
DOCTORATES

In the fall of 1978, 500 full-time and 85 part-time Ph.D. candidates were enrolled, showing that doctoral enrollments have remained relatively stable since the Fall of 1976 (see Table 1).

The 110 doctorate degrees awarded in 1977-78 represent a nine percent decrease from 1976-77, and the second lowest number since academic year 1966-67 (see Chart 1 and. Appendix A-1). There has been a decline in the number of doctorate degrees granted in the past two years. Doctorate degrees were awarded by 49 percent of all institutions; but Massachusetts Institute of Technology awarded two times as many doctorates (20) as the next leading institution, University of Michigan (10). The Univerșity of Wisconsin awarded the third largest number of doctorate degrees (7).

The decrease in the number of doctorate degrees awarded in nuclear engineering in 1977-78 followed a pattern of general decline in all engineering doctorates awarded, so that there was little change in nuclear engineering's share of all engineering doctorates (4.27 percent). Against the long-term decrease in all engineering doctorates awarded dating back to 1971-72 (see Table 2), the number and percentage of nuclear engineering doctorates has fluctuated.

In 1977-78, both the number of doctorate degrees awarded and the enrollment of doctoral candidates: were largely in specific nuclear engineering programs (see Table 3). Only about two percent of those enrolled and six percent of Ph.D. degrees awarded were in other engineering disciplines specializing with a nuclear option.

\section{MASTERS}

In the fall of 1978, there were 818 full-time and 246 part-time master's candidates enrolled. Although the number of full-time master's level candidates remained relatively stable, the part-time enroliment decreased by 31 percent. Total enrollment figures of 1,064 (see Table 1) represent the lowest number of master's candidates since the fall of 1973. 
TABLE 2

Nuclear Engineering Degrees as a Percentage of All

Engineering Degrees by Degree Level

Engineering Degrees by

BACHELORS

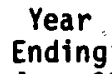

June 30

1967

1968

1969

1970

1971

1972

1973

1974

1975

1976

1977

1978

SOURCE:

$36,186 \quad 167$

38,002

39,972

42,966

43,167

44,190

43,429

41,407

167

251

315

424.

448

536

663

628

529

648

758

777

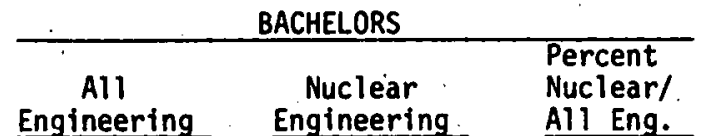

All Eng.

\begin{abstract}
0.46
\end{abstract}
0.66 .

0.79 .

0.99

1.04

1.21

1.53

1.52

1.38

1.71

1.89

1.69 .
MASTERS

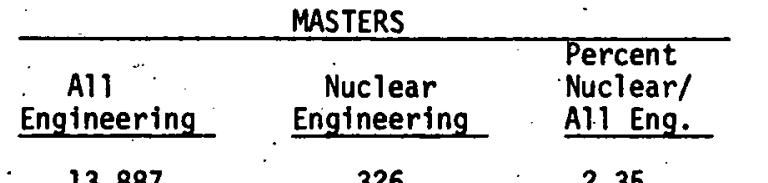

13,887

15,152

14,980

15,548

16,383

17,356

17,152

15,885

15,549

16,506

16,517

16,182
326

320

385

413

414

- 436

452

465

475

468

554

487

Data for all engineering degrees supplied by Engineerin for nuclear engineering degrees, Department of Energy. 
TABLE 3

Undergraduate, Master's and Doctorate Enroliments and Degrees Granted

in Nuclear Engineering or Other Engineering Fields with Nuclear Option, 1975-1978 (Percent Distribution)

\section{Nuclear engineering Chemical \\ Engineering science \\ Electrical \\ Mechanical \\ other}

\begin{tabular}{rrrr}
\multicolumn{4}{c}{ BACHELORS } \\
\hline$\frac{1975}{75}$ & $\frac{1976}{75}$ & $\frac{1977}{69}$ & $\frac{1978}{68}$ \\
2 & 3 & 4 & 3 \\
5 & 4 & 4 & 6 \\
5 & 4 & 5 & 6 \\
8 & 9 & 11 & 12 \\
5 & 4 & 7 & 7
\end{tabular}

\begin{tabular}{|c|c|c|c|c|}
\hline & \multicolumn{4}{|c|}{ BACHELORS } \\
\hline & $1974-75$ & $1975-76$ & $1976-77$ & $1977-78$ \\
\hline $\begin{array}{l}\text { Nuclear engineering } \\
\text { Chemical } \\
\text { Engineering science } \\
\text { Electrical } \\
\text { Mechanical }\end{array}$ & $\begin{array}{r}72 \\
1 \\
6 \\
3 \\
14\end{array}$ & $\begin{array}{r}73 \\
5 \\
3 \\
6 \\
7\end{array}$ & $\begin{array}{r}70 \\
6 \\
3 \\
5 \\
12\end{array}$ & $\begin{array}{r}70 \\
4 \\
7 \\
4 \\
11\end{array}$ \\
\hline other & $\begin{array}{r}14 \\
4\end{array}$ & 6 & $\begin{array}{r}16 \\
5\end{array}$ & $\begin{array}{r}11 \\
4\end{array}$ \\
\hline
\end{tabular}

\begin{tabular}{ccccc}
\multicolumn{4}{c}{ MASTERS } \\
\hline$\frac{1975}{90}$ & $\frac{1976}{88}$ & $\frac{1977}{88}$ & $\frac{1978}{96}$ \\
$\star$ & & $\star$ & $\star$ & - \\
3 & 2 & 2 & 1 \\
$\star$ & 1 & $\star$ & - \\
7 & 8 & 4 & 3 \\
- & $\star$ & & 1 & -
\end{tabular}

\begin{tabular}{|c|c|c|c|c|}
\hline \multicolumn{5}{|c|}{ DOCTORATES } \\
\hline 1975 & 1976 & 1977 & & 1978 \\
\hline 97 & 95 & $\begin{array}{r}95 \\
\text { * }\end{array}$ & - & 98 \\
\hline$i$ & - & 1 & - & 1 \\
\hline$\star$ & * & - & & - \\
\hline 2 & 5 & 3 & & 1 \\
\hline - & - & - & & \\
\hline
\end{tabular}

DEGREES GRANTED

\begin{tabular}{|c|c|c|c|}
\hline \multicolumn{4}{|c|}{ MASTERS } \\
\hline $1974=75$ & $1975-76$ & $1976-77$ & $1977-78$ \\
\hline 90 & 90 & 92 & 95 \\
\hline $\begin{array}{l}1 \\
2\end{array}$ & $\begin{array}{l}1 \\
1\end{array}$ & 1 & - \\
\hline 1 & $\star$ & * & 1 \\
\hline 6 & 8 & 7 & 4 \\
\hline
\end{tabular}

\begin{tabular}{|c|c|c|c|}
\hline \multicolumn{4}{|c|}{ DOCTORATES } \\
\hline $1974-75$ & $1975-76$ & $1976-77$ & $1977-78$ \\
\hline 91 & 96 & 94 & 95 \\
\hline 1 & - & 1. & 2 \\
\hline 2 & - & 2 & 1 \\
\hline - & 1 & - & - \\
\hline 6 & 3 & 3 & 3 \\
\hline - & - & - & - \\
\hline
\end{tabular}

*Less than $\frac{1}{2}$ of 1 percent.

NOTE: Percentages of enrollments and degrees granted are based on total enrollments and degrees granted by all institutions reporting in that respective year. Percentages may not add to 100 percent because of rounding.

SOURCE: ERDA, OUP, Nuclear Engineering Enrollments and Degrees, 1975, ERDA-76-102, July 1976; DOE, IR, DLAMA, Nuclear Engineering Enrollments and Degrees, 1977, D0E/IR-011, 1978; and 1977-78, Department of Energy. 
In addition to this, the number of master's degrees awarded (487) decreased both numerically and as a percentage of all engineering masters (see Table 2). Although 75 percent of all institutions (52) granted master's degrees, ten schools accounted for 52 percent of the total degrees awarded. Massachusetts Institute of Technology, alone, accounted for 13 percent, granting 63 master's degrees.

Ninety-six percent of those enrolled in nuclear engineering master's programs were in unique programs, and only four percent were in other engineering disciplines with nuclear option. This contrasts with only 88 percent in unique nuclear engineering programs in the fall of 1977. The percentage of master's degrees awarded in the discrete nuclear engineering discipline has also increased from 90 percent in 1974-75 and 1975-76, and 92 percent in 1976-77 to 95 percent in 1977-78.

\section{BACHELORS}

Enrollment of third year students for fall 1978 was 898 (885 fulltime and 13 part-time); for fourth year students, enrollment was 1,010 (1,003 full-time and 7 part-time); and for fifth year students, enrollment was 176 (173 full-time and 3 part-time). Despite the decrease in total enrollment of undergraduates, from 2,160 in 1977 to 2,084 in 1978, the number of fifth year students rose (see Table 1). Enroliment at four institutions (University of Florida, University of Maryland, Purdue University, and Rennselaer Polytechnical Institute) accounted for 72 percent of the increase in fifth year student enrollment.

There were 777 bachelor's degrees awarded during 1977-78, the highest number reported since the survey's beginning (see Chart 1 and Table 2). The percentage of all bachelor's engineering degrees which were in nuclear engineering dropped from 1.89 percent in 1976-77 to 1.69 percent in 1977-78. Even so, this percentage is the third highest since 1967 (see Table 2).

Enrollment in other engineering disciplines with nuclear option has increased from 31 percent of nuclear engineering enrollments in 1976-77 to 34 percent in 1977-78 (see Table 3). A smal1 decrease (from 31 in 1976-77 to 30 percent in 1977-78) was reported in the number of bachelor's degrees awarded in nuclear option programs. 
Placement of 1977-78 Ph.D. nuclear engineering graduates varied little from 1976-77 (see Table 4). The largest decreases occurred in those hired by Government-owned contractor-operated installations (from 22 to 15). As in 1976 and 1977, the largest single employer of new doctorates in 1978 was private industry (31 percent).

The largest group of master's degree holders (29 percent) was also placed within industry, while the next largest proportion of graduates chose further study (20 percent). However, the biggest percentage decrease was reported in industrial employment. Part of this decrease could be accounted for by the many graduates (30 percent) in the unknown placement category. Other placement categories experienced only minor variations.

There were 217 bachelor's degree holders (28 percent) who found employment in private industry (down from 284, or 38 percent, in . the last survey). The next largest group of graduates chose further study (169 graduates, or 22 percent). The latter category also showed a decrease from the previous year (from 193 to 169). As with the master's degree recipients, the number of graduates whose placement is unknown increased.

Clearly, the largest group of graduates at all levels was hired by private industry, which hired 394 graduates, or about 31 . percent of new nuclear engineers entering the labor market.

\section{WOMEN AND MINORITIES}

The total number of women enrolled at the third and fourth year undergraduate levels and master's level has increased over the past six years (see Table 5). The undergraduate enrollment of 104 women represents a two percent increase over 1976-77 figures, whereas master's candidates show a seven percent increase. A substantial decrease was reported in the number of women doctoral candidates, from 20 candidates in 1976-77 to seven in the latest survey. However, in the degrees granted category, the proportion of women increased at the bachelor and doctoral levels, but at the master's level the proportion remained the same. 
TABLE 4

Placement of 1977-78. Nuclear Engineering Graduates

by Degree Leve1

BACHELOR'S

Number Percent
MASTER'S Number Percent
DOCTORATES

Number Percent
Further study

U.S. academic employment

Federal government employment

GOCO (Government-owned/ contractor-operated installations)

State and local

government

Industrial employment

Foreign employment

Military

Other

Seeking employment

Unknown

TOTALS
169

22

4

13

$\cdot 2$

39

5

95

20

10

17

9

1

3

1

19

4

31

6

6
2.17
3

51

0

1

1

1

143

29

20.4

25.5

31

0 *

$\frac{274}{777} \quad \frac{35}{100}$

$\frac{147}{487} \cdot \frac{30}{100}$
15

14

43

0 . $\quad$ *

$34 \quad 31$

10.9

- 11

22

11

$\frac{16}{110} \quad \frac{15}{100}$

*Less than $1 / 2$ of one percent

NOTE: Percentages are rounded to nearest whole number.

SOURCE: Department of Energy. 
As in the previous survey, Black student enrollment stands at one percent at all levels. Even so, the total number of Black students decreased, reflecting the general drop in nuclear engineering enrollments. The same picture is evident in the number of degrees awarded to Blacks, except that seven Blacks received bachelor degrees compared with one the previous year.

Participation by Spanish-surnamed students remained at a very low level and accounted for only one percent, or less, of both student enrollment and degrees granted.

Asian American students continue to represent relatively low percentages of persons enrolled and receiving degrees, but there has been an increase (from 15 to 21) since Fall 1977 in the number of Asian American master's candidates.

\section{FOREIGN NATIONALS}

There was a decrease in the number of foreign nationals enrolled in the undergraduate program. The 142 undergraduate students are a seven percent decrease over the numbers for 1976-77. Master's degree candidates increased by one student to 313. Doctoral enrollment increased to 275 students from 202 in 1976-77. Also, as a percentage of all nuclear engineering students, the doctoral enrollment for foreign nationals rose to 50 percent; foreign nationals are 32 percent of the master's candidates.

For those foreign nationals receiving nuclear engineering degrees, the only increase was at the Bachelor's level (from 32 to 41). The number of Master's degrees granted decreased from 127 to 103, whereas the number of doctorates decreased by one (from 36 to 35). Interestingly enough, even though there was an overall decrease in the number of graduate degrees granted, the percentages of total nuclear engineering students who were foreign nationals increased.

\section{REGIONAL DISTRIBUTION}

At the undergraduate level, enrollment was highest in educational institutions located in three regions (Middle Atlantic, East North-Central, and South Atlantic), which accounted for 52 percent of all undergraduate enrollments in nuclear engineering (see Appendix A-6). Similarly, sixty percent of the bachelor's degrees were 
TABLE 5

Participation by

Foreign Nationals, Women and Minorities

in Nuclear Engineering Programs

1973-1978

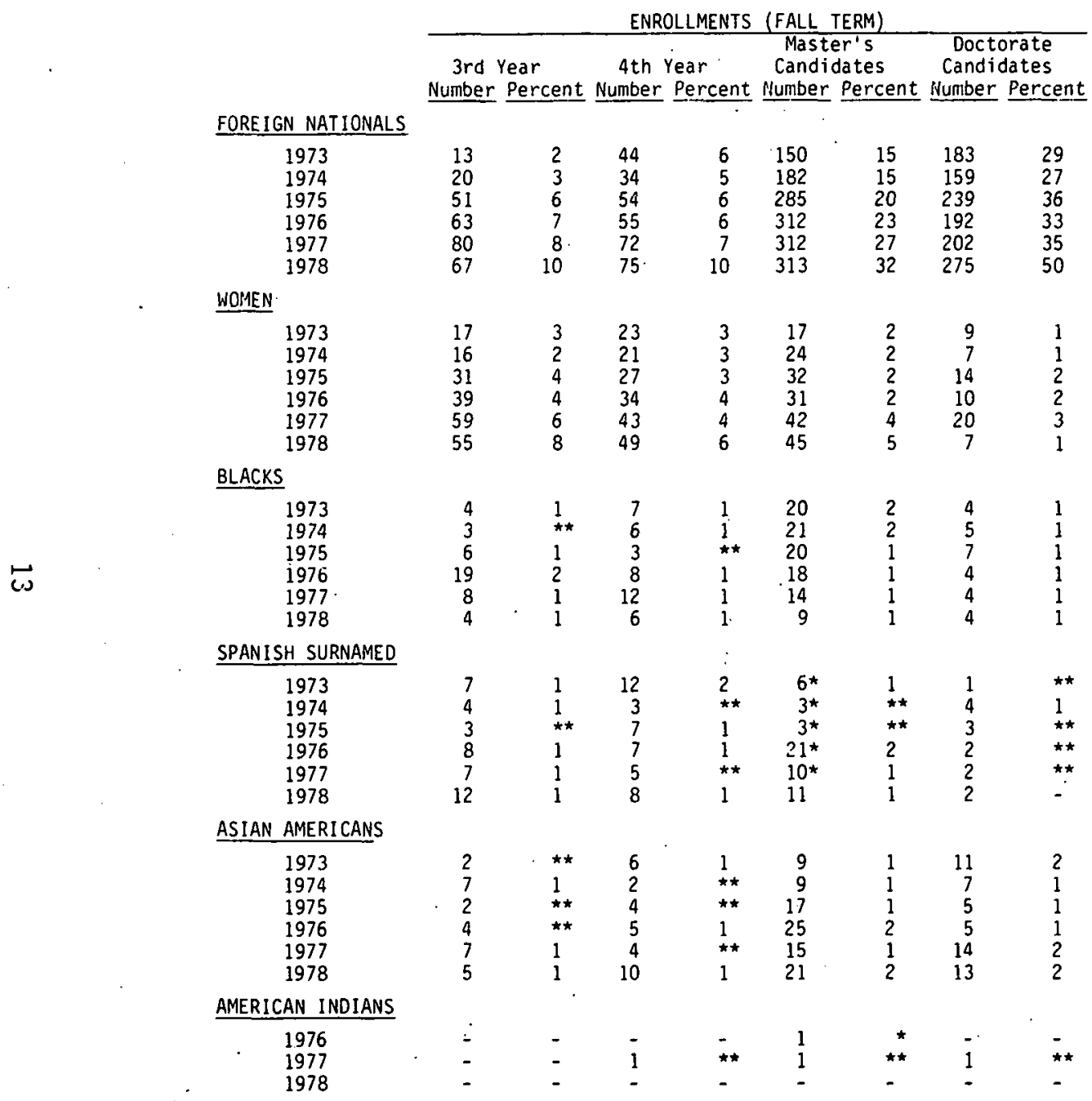

DEGREES GRANTED (YEAR ENDING JUNE 30)

Bachelor's Master's Doctorate

Number Percent Number Percent Number Percent

$\begin{array}{rrrrrr}16 & 3 & 58 & 13 & 28 & 22 \\ 8 & 1 & 61 & 13 & 28 & 22 \\ 39 & 8 & 76 & 17 & 30 & 30 \\ 20 & 3 & 81 & 17 & 47 & 32 \\ 32 & 4 & 127 & 23 & 36 & 30 \\ 41 & 7 & 103 & 26 & 35 & 37\end{array}$

$\begin{array}{rrrlll}6 & 1 & 2 & \star * & - & - \\ 13 & 2 & 5 & 1 & 1 & 1 \\ 14 & 2 & 11 & 2 & 2 & 2 \\ 14 & 2 & 7 & 2 & - & - \\ 15 & 2 & 13 & 2 & 2 & 2 \\ 28 & 5 & 9 & 2 & 4 & 4\end{array}$

$\begin{array}{llllll}9 & 2 & 7 & 2 & 2 & 2 \\ 3 & 1 & 8 & 2 & - & - \\ 4 & 1 & 5 & 1 & - & - \\ 6 & 1 & 2 . & \star \star & - & - \\ 1 & \star \star & 6 & 1 & 1 & 1 \\ 7 & 1 & 5 & 1 & 1 & 1\end{array}$

$\begin{array}{cccccc}5 & 1 & - & - & 1 & 1 \\ 3 & 1 & 2 * & * * & 2 & 2 \\ 3 & 1 & 6 * & 1 & 1 & 1 \\ 4 & \star * & 10^{*} & 3 & - & - \\ 1 & * \star & 3 * & 1 & 1 & 1 \\ 4 & 1 & 4 & 1 & - & -\end{array}$

$\begin{array}{lllllll}3 & \star \star & 4 & 1 & 3 & 2 \\ 2 & \star \star & 5 & 1 & - & - \\ 1 & \star \star & 7 & 1 & 2 & 2 \\ 4 & \star \star & 2 & & \vdots \star & 3 & 2 \\ 3 & \star \star & 7 & 1 & 2 & 2 \\ 3 & 1 & 4 & \ddots & 1 & 2 & 2\end{array}$

*These figures do not include the University of Puerto Rico.

**Less than $\frac{1}{2}$ of 1 percent.

NOTE: Percentages of enrollment and degrees granted are based on total enrollment and degrees granted by all institutions reporting in that respective year.

SOURCE: Department of Energy. 
granted by states in these same three regions. The state of New York enrolled the most undergraduates of any state and awarded nine percent of the bachelor's degrees. Texas followed close behind with eight percent of the undergraduate enrollment.

Enroliment of graduate students followed a similar pattern. The Middle Atlantic, East North-Central, and South Atlantic regions contained the highest numbers of graduate degree candidates and accounted for approximately 53 percent of total graduate enroliment. Although Massachusetts contained more master's candidates than any other state, Illinois had the largest contingent of Ph.D. candidates. Massachusetts granted the largest number of master's degrees in 1977-78, but the leading regions were the East North-Central and South Atlantic with 84 master graduates. The New England region, specifically Massachusetts, posted the largest number of doctorates granted in nuclear engineering. 


\section{APPENDICES}

Appendix A - Statistical Tables

Appendix B - Addresses

Appendix C - Survey Materials 
APPENDIX A-1

NUCLEAR ENGINEERING DEGREES GRANTED 1968-1978

$B=$ Bacheloris

$8 y$ Institution

= Masters

$D=$ Doctorate

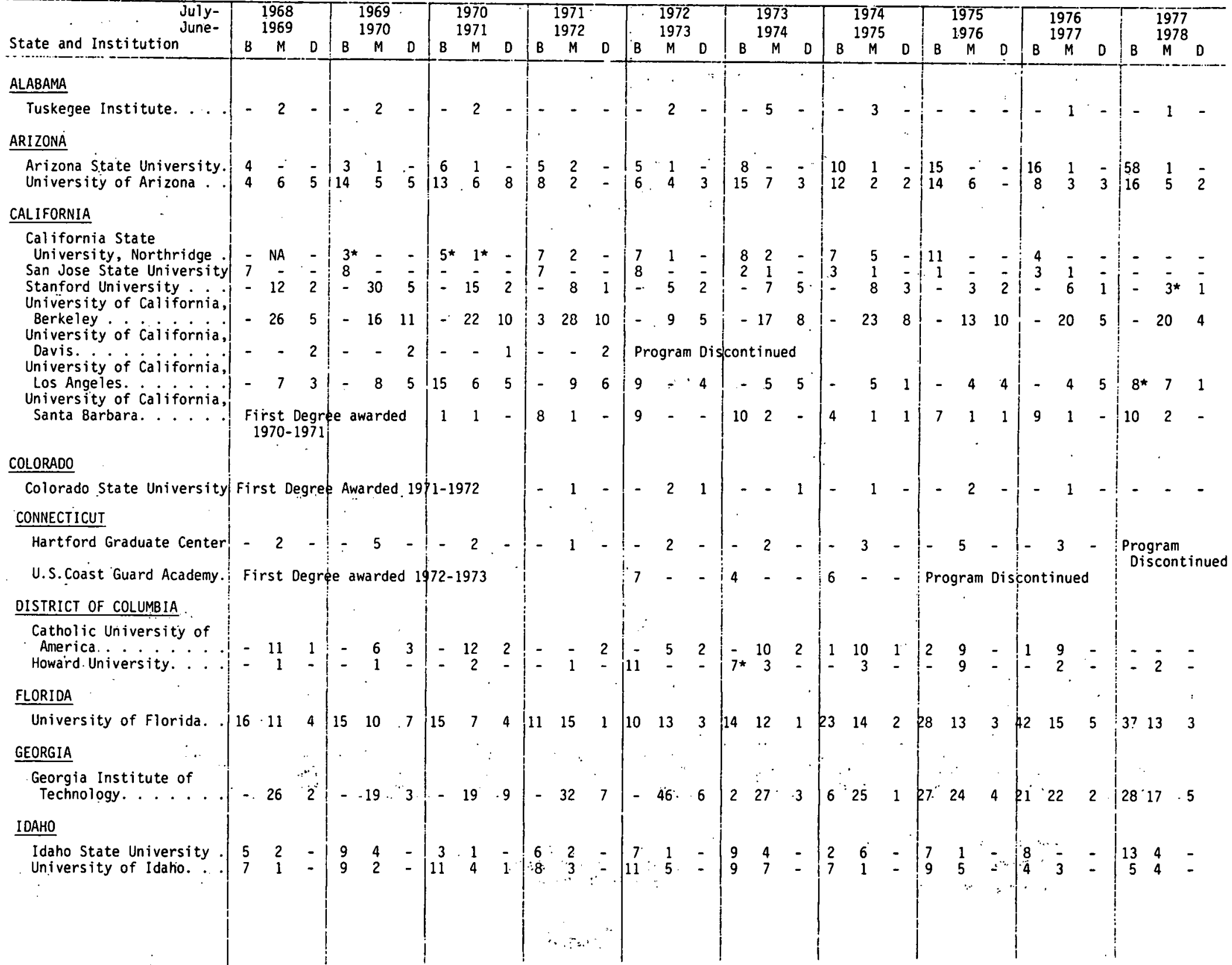




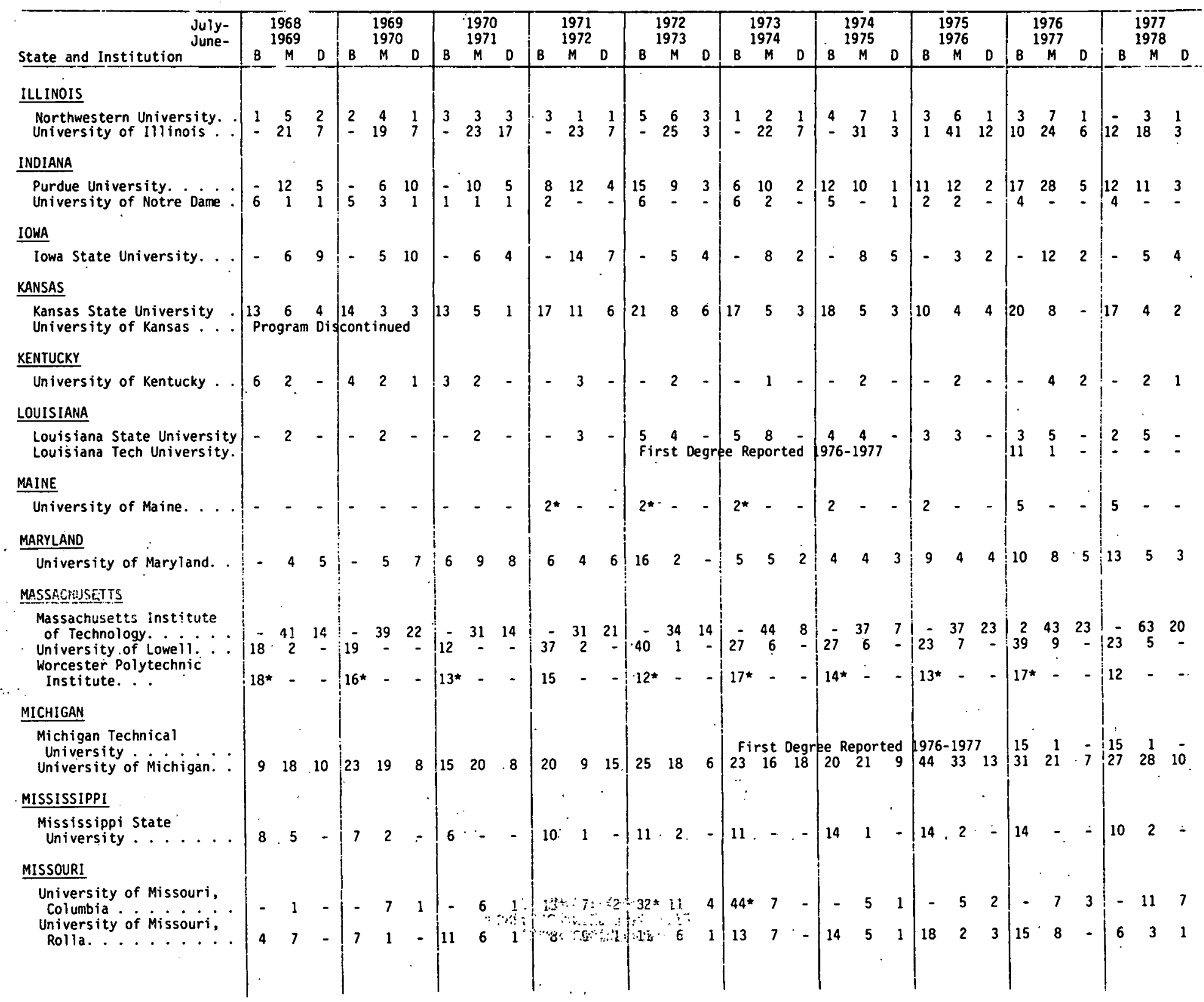




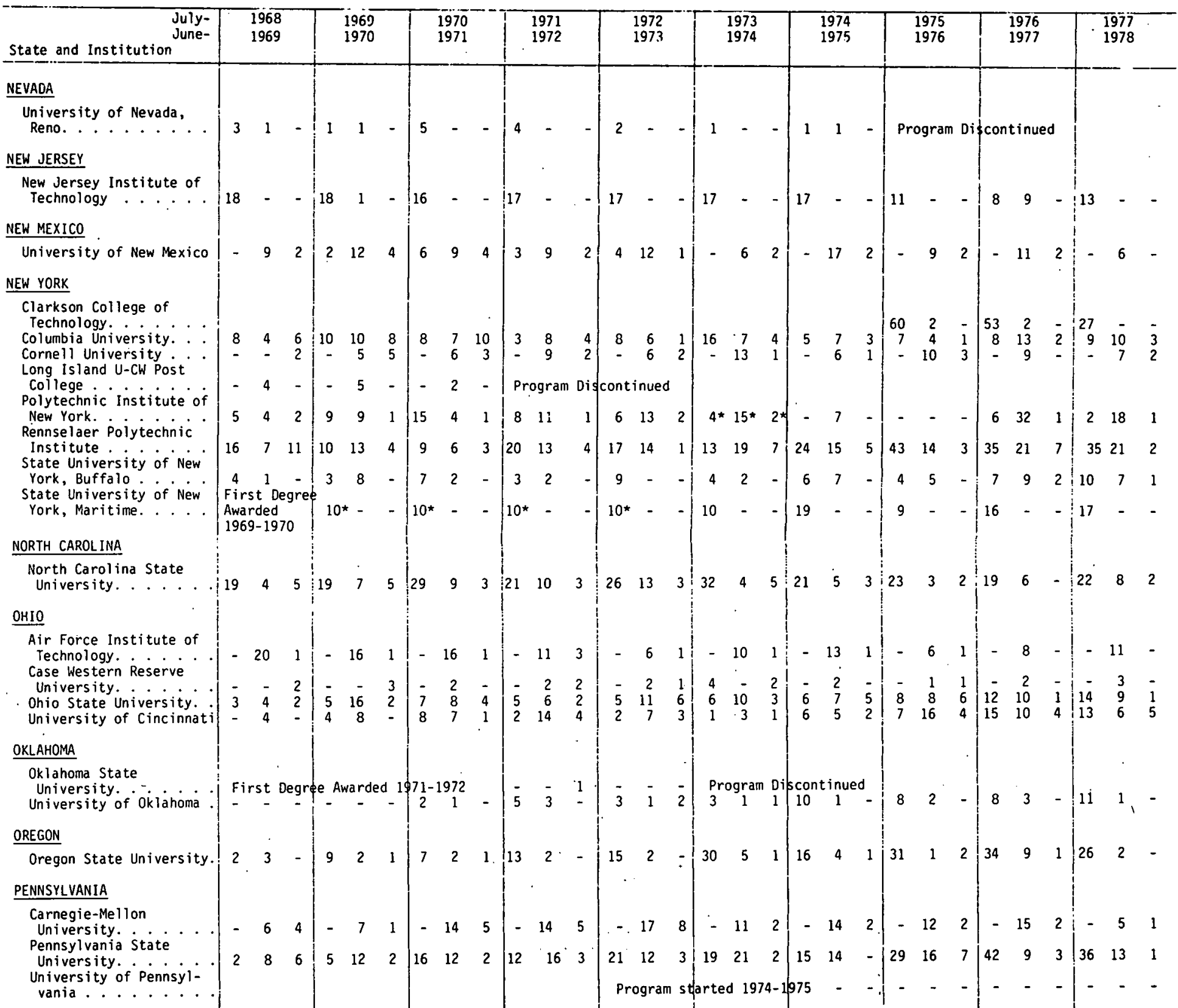




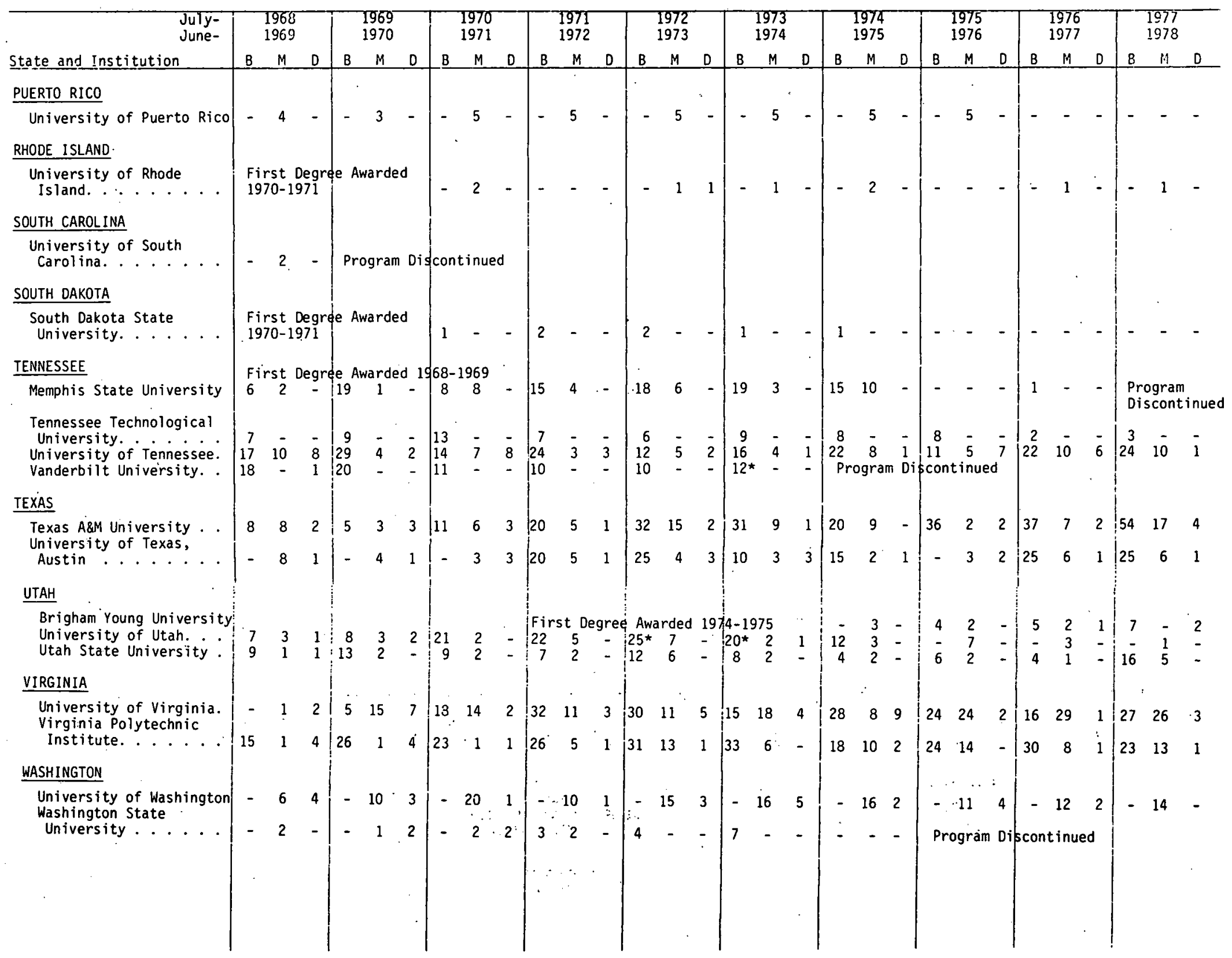




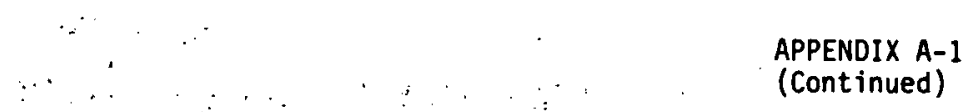

NUCLEAR ENGINEEERING DEGREES GRANTED 1968-1978

$B=$ Bachelors

By Institution

$M=$ Masters

D = Doctorate

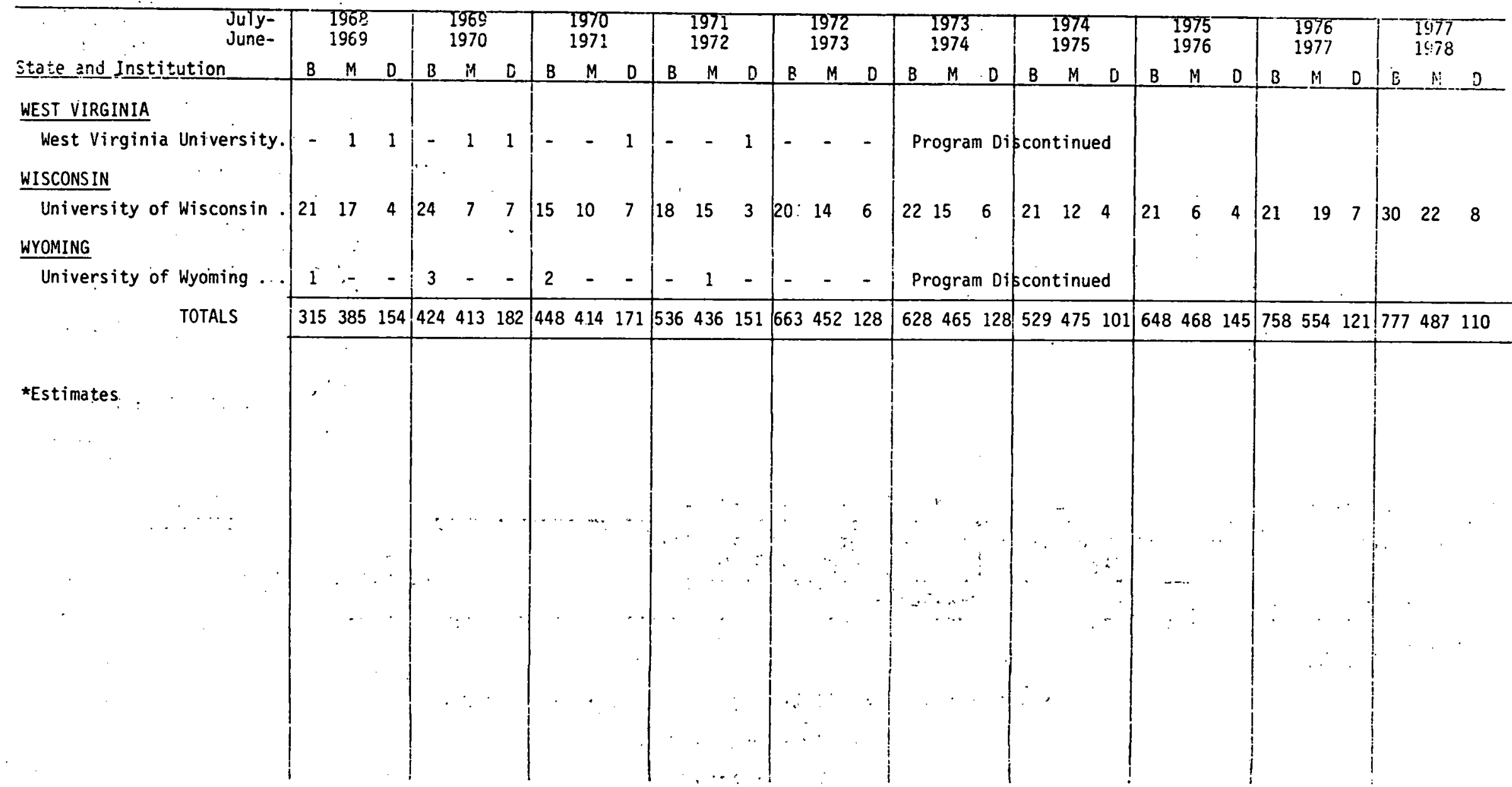


APPENDIX A-2

NUCLEAR ENGINEER ING

ENROLLMENTS AND DEGREES IN SUBF IELDS BY INSTITUTION

$T=F U L L$ TIME

PT = PART TIME

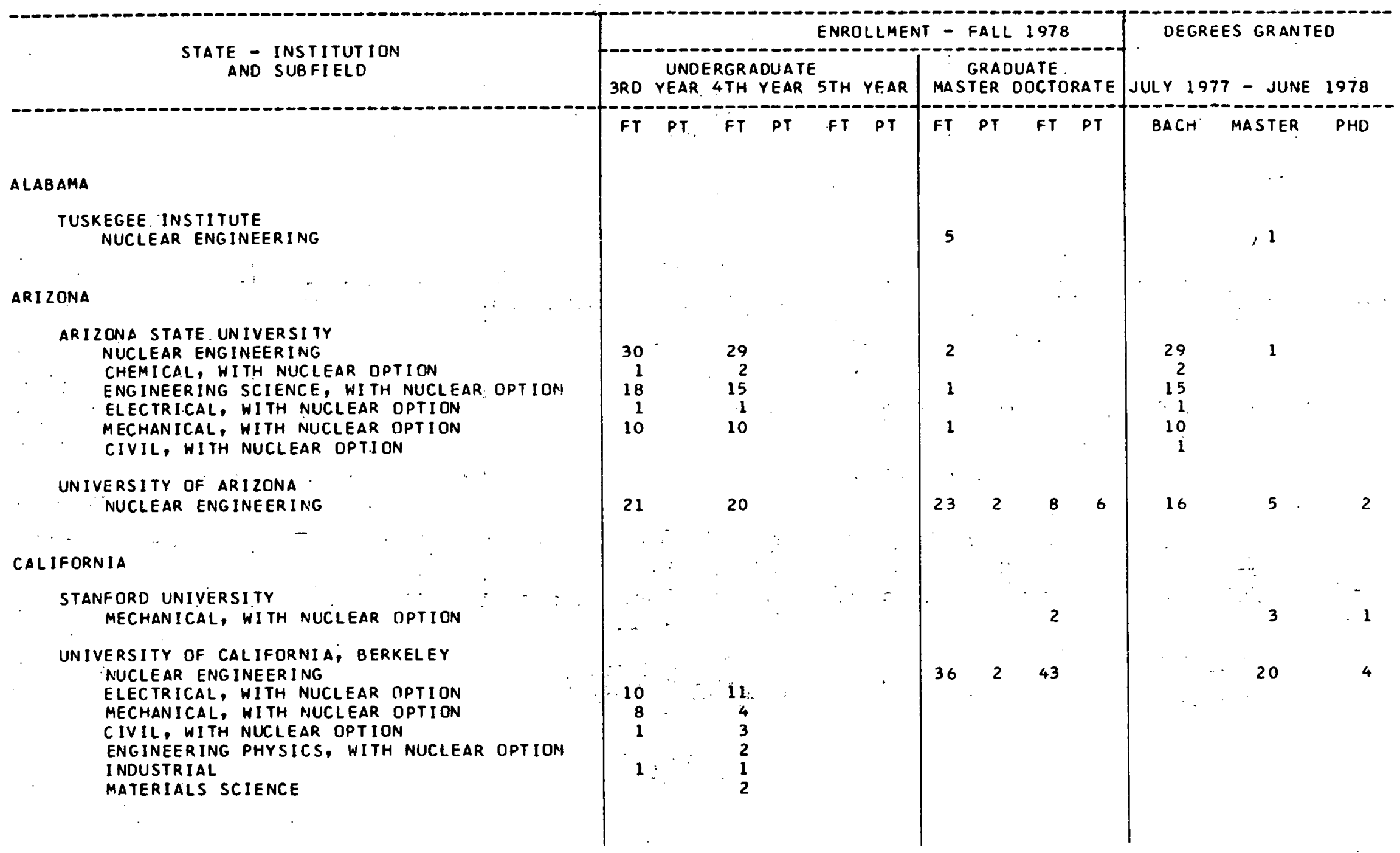




\section{APPENDIX A-2 (CONTINUED)}

NUCLEAR ENGINEER ING

ENROLLMENTS AND DEGREES IN SUBFIELDS BY, INSTITUTION

$F T=F U L L$ TIME

$P T=$ PART TIME

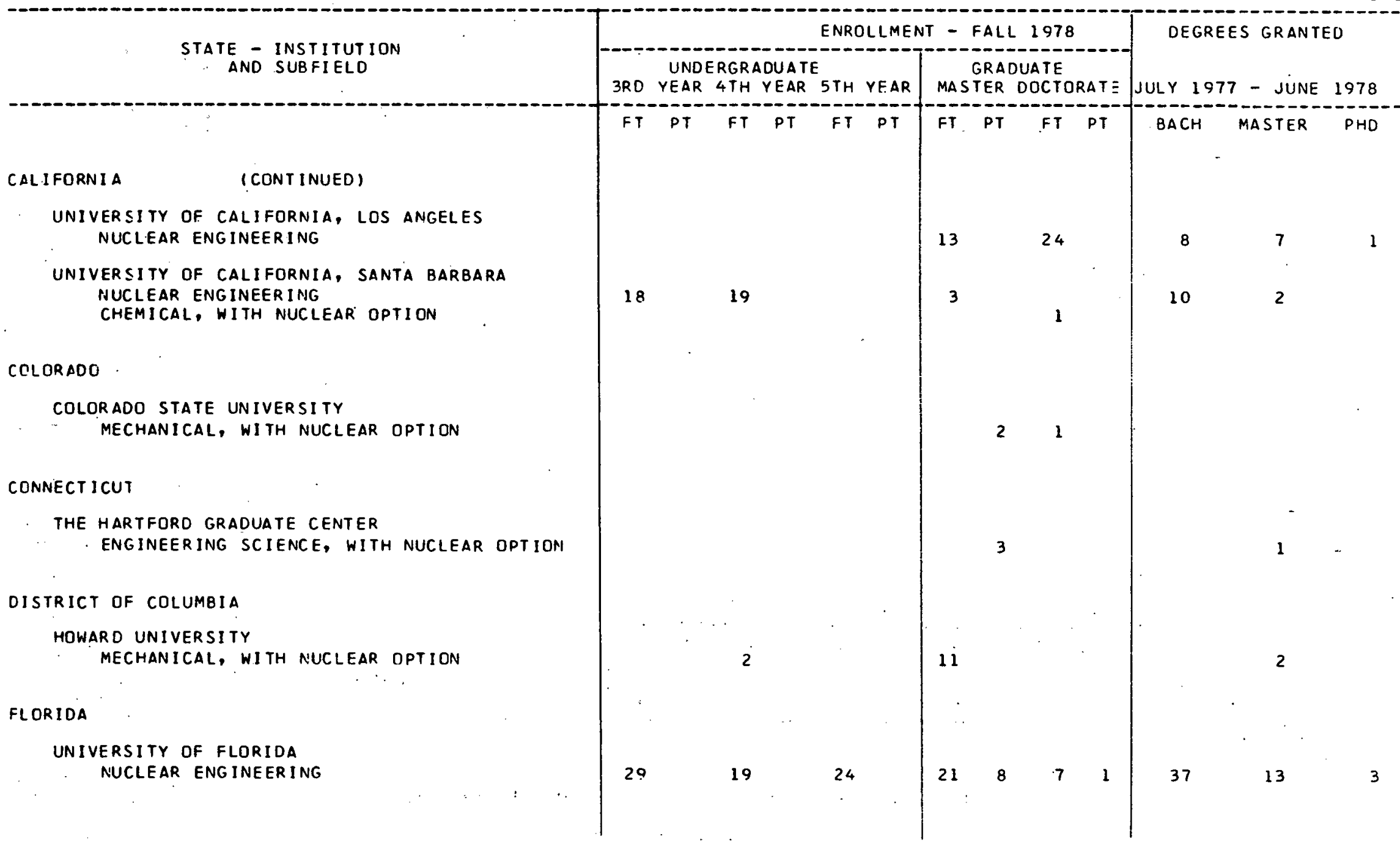


APPENDIX A-2 (CONTINUED)

NUCLEAR ENGINEER ING

ENROLLMENTS AND OEGREES IN SUBFIELOS BY INSTITUTION

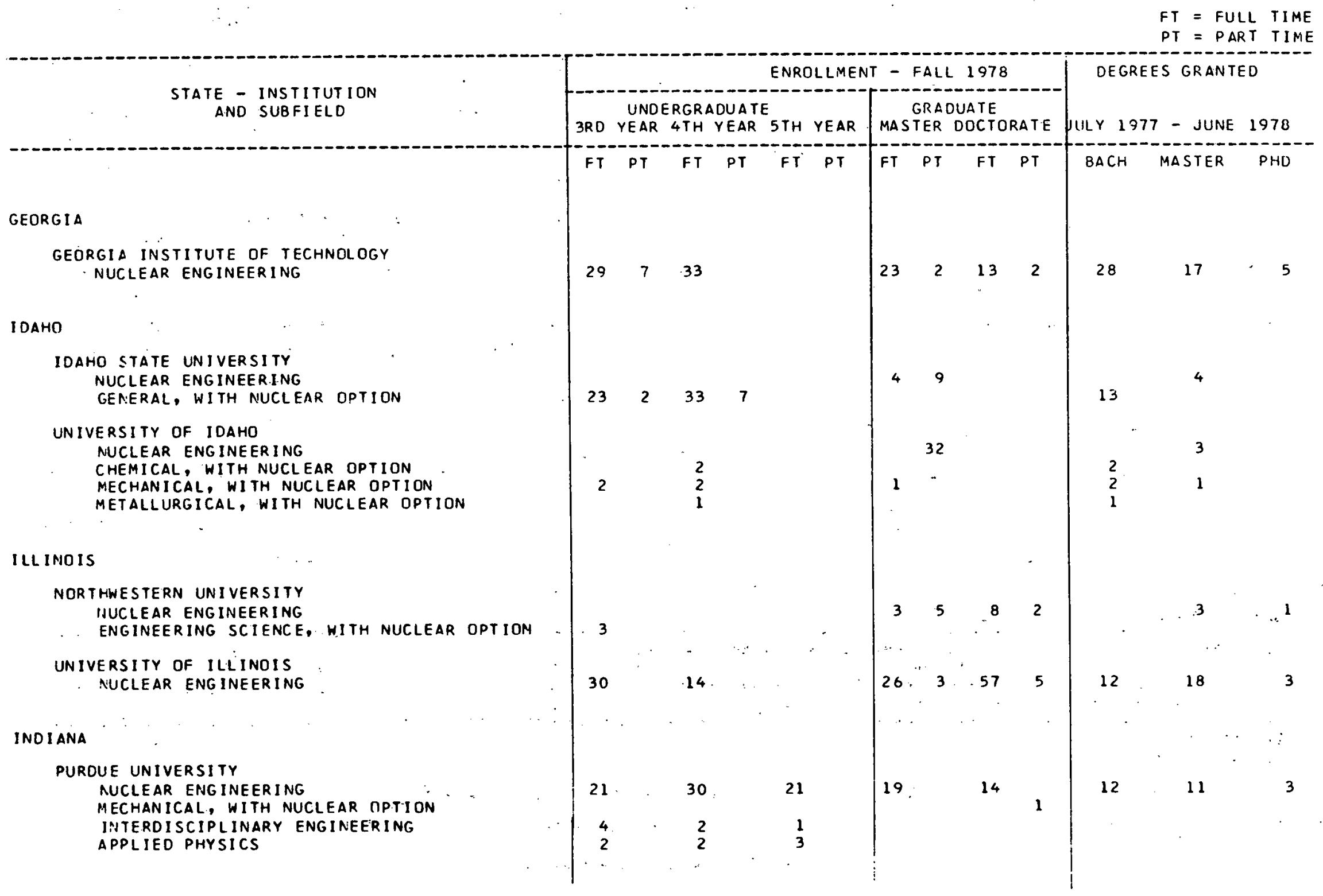




\section{APPENDIX A-2 (CONT INUED)}

NUCLEAR ENGINEERING

ENROLLMENTS AND DEGREES IN SUBFIELDS BY INSTITUTION

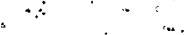

FT = FULL TIME

STATE - INSTITUTION

INOIANA

(CONTI NUED)

UNIVERSITY OF NOTRE DAME MECHANICAL, WITH NUCLEAR DPTION

IOWA

IOWA STATE UNIVERSITY

NUCLEAR ENG INEERING

\section{KANSAS}

KANSAS STATE UNIVERSITY NUCLEAR ENG INEERING

\section{KENTUCKY}

UN.IVERSITY OF KENTUCKY MECHANICAL, WITH NUCLEAR DPTION

\section{LOUISIANA}

LOUISIANA STATE UNIVERSITY

NUCLEAR ENG INEER ING

ENG INEERING SCIENCE;, HITH NUCLEAR OPTION

(12


APPENDIX A-2 (CONTINUED)

NUCLEAR ENGINEERING

ENROLLMENTS AND DEGREES IN SUBFIELDS BY INSTITUTION

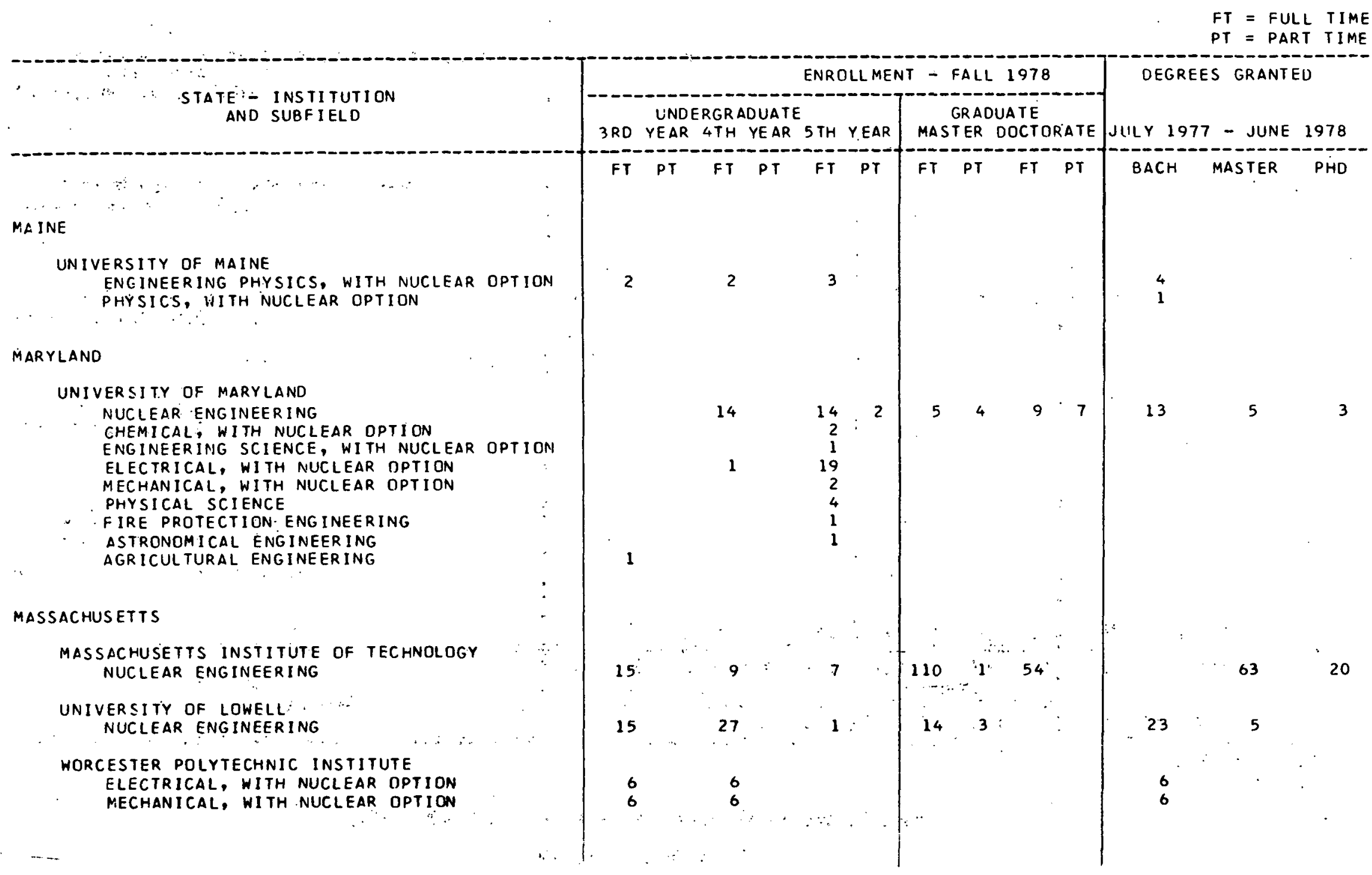




\section{APPENDIX A-2 (CONTINUED)}

NUCLEAR ENGINEER ING

ENROLLMENTS AND DEGREES IN SUBFIELDS BY INSTITUTION

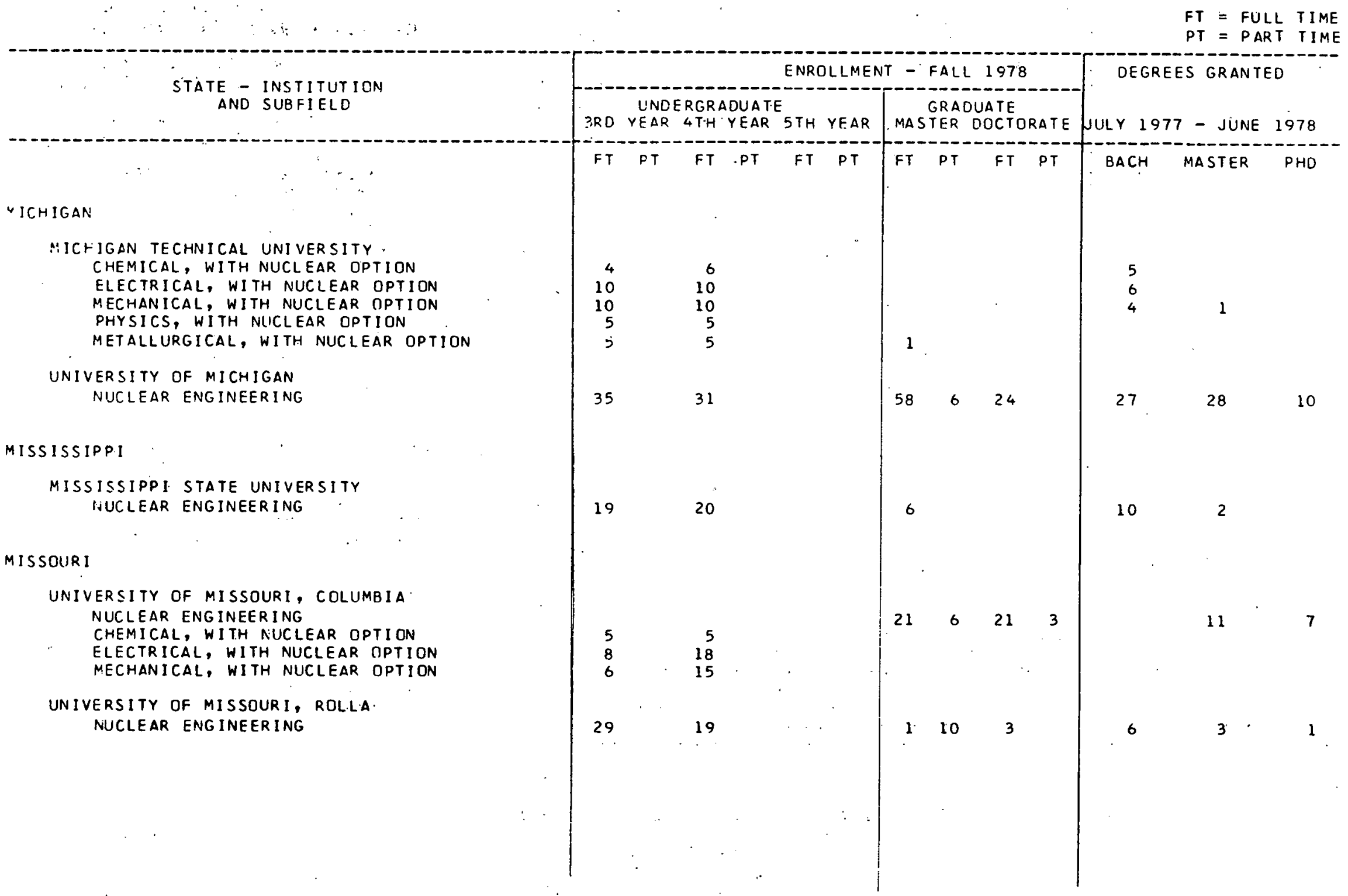


APPENDIX A-2 (CONTINUED)

NUCLEAR ENGINEER ING

ENROLLMENTS ANO DEGREES IN SUBFIELDS BY INSTITUTION

$F T=F U L L$ TIME

$P T=P A R T$ TIME

STATE INSTITUTION
AND SUBFIELD
NEW JERSEY INSTITUTE OF TECHNOLOGY
CHEMICAL, WITH NUCLEAR OPTION
ENGINEERING SCIENCE, WITH NUCLEAR OPT ION
ELECTRICAL, WITH NUCLEAR OPTION
MECHANICAL, WITH NUCLEAR DPTION
COMPUTER SCIENCE, WITH NUCLEAR OPTION

NEW MEXICO

UNIVERSITY OF NEW MEXICO NUCLEAR ENGINEERING

NEW YORK

CLARKSON COLLEGE OF TECHNOLOGY CHEMICAL, HITH NUCLEAR OPTION ELECTRICAL, HITH NUICLEAR OPTION MECHANICAL, WITH NUCLEAR OPTION CIVIL, WITH NUCLEAR OPTION

COLUMBIA UNIVERSITY

NUCLEAR ENG INEERING

CORNELL UNIVERSITY

NUCLEAR ENG INEERING

POLYTECHNIC INSTITUTE OF NEW YORK NUCLEAR ENG INEERING

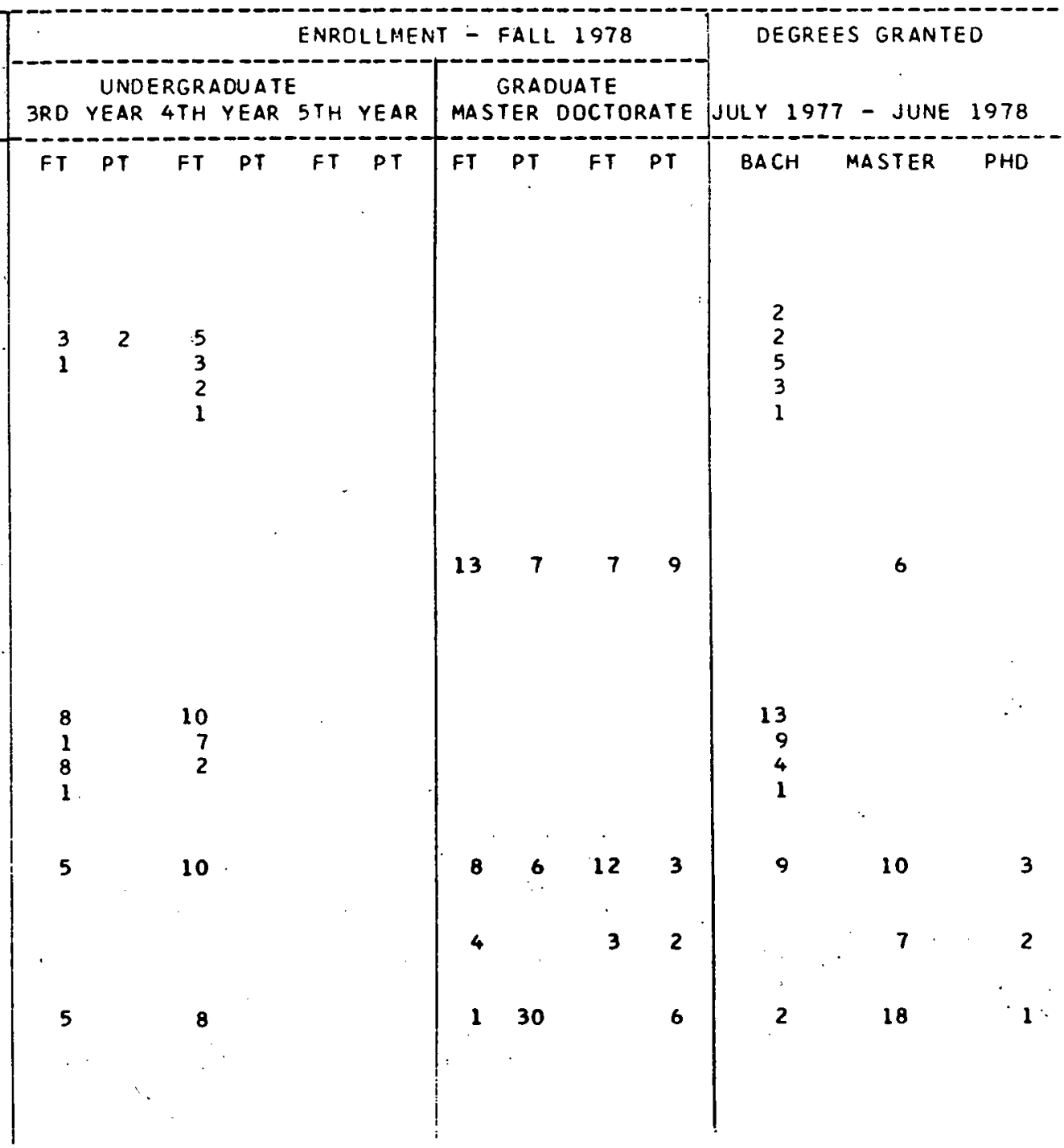


APPENDIX A-2 (CONTINUED)

NUCLEAR ENGINEERING

ENROLLMENTS AND DEGREES IN SUBF IELDS BY INSTITUTION

PT $=$ PART TIME

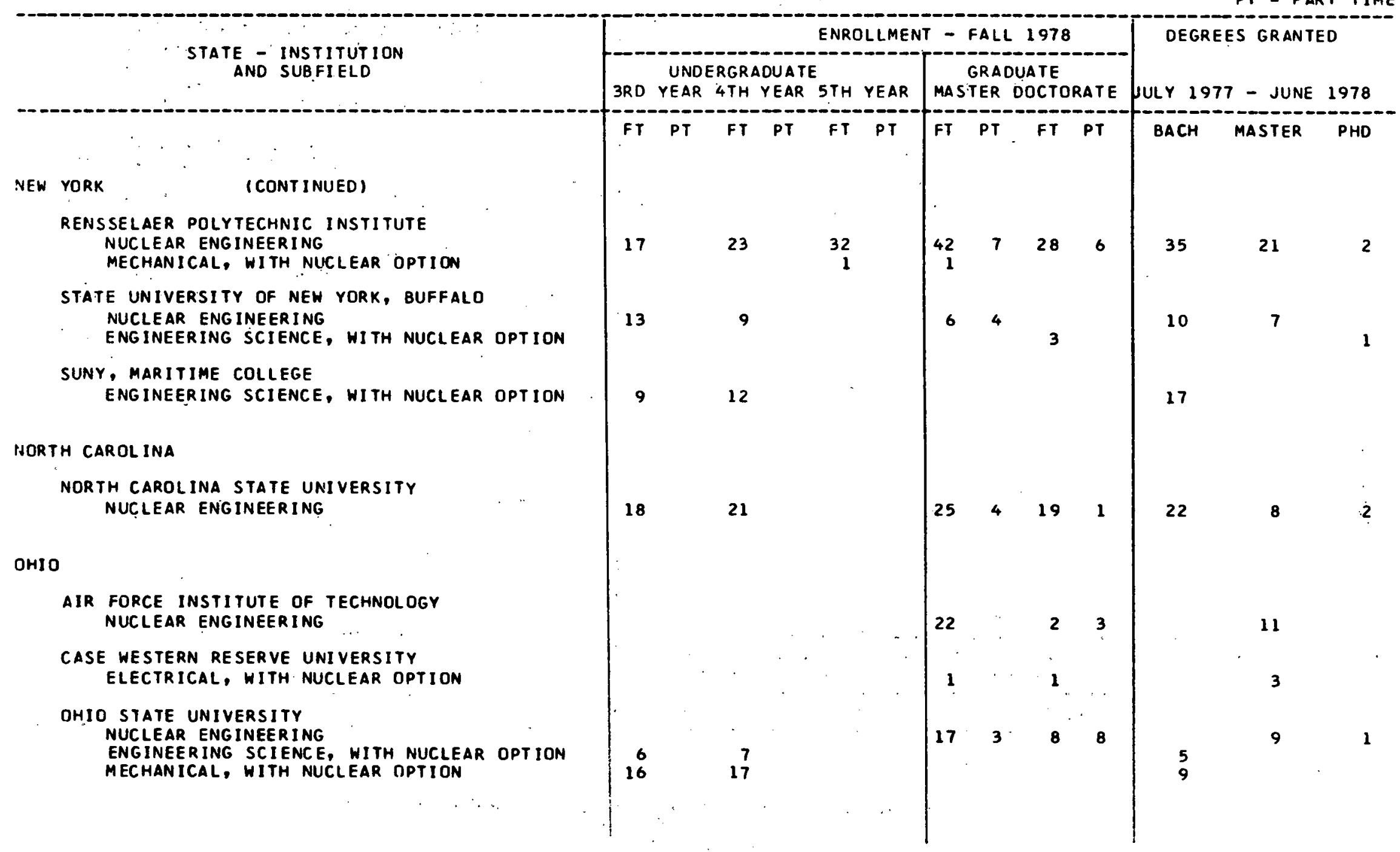


APPENOIX A-2 (CONT INUED)

NUCLEAR ENGINEERING

ENROLLMENTS AND DEGREES IN SUBFIELDS BY IMSTITUTION

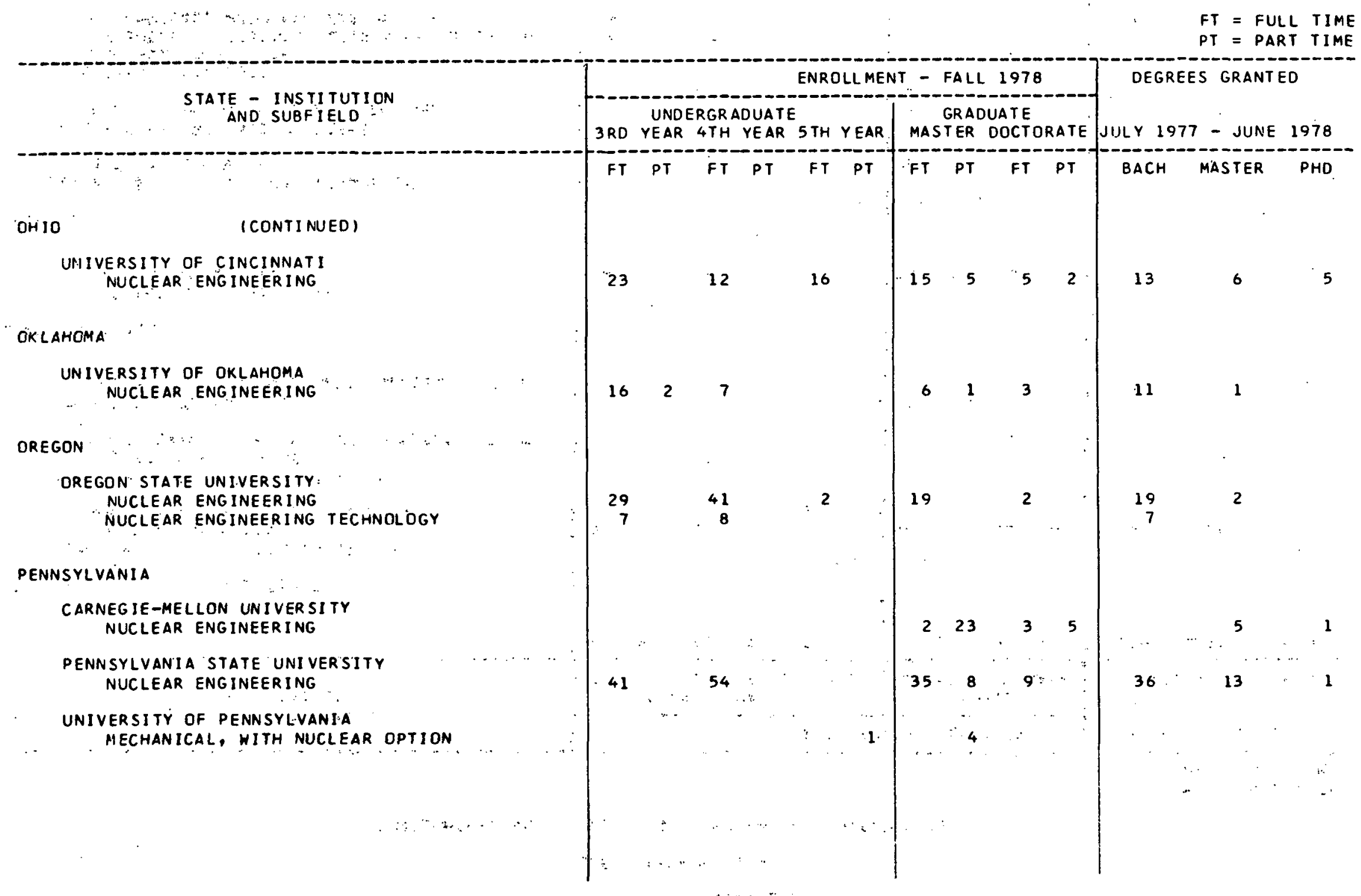


APPENDIX A-2 (CONT INUED)

NUCLEAR ENGINEERING

ENROLLMENTS AND DEGREES IN SUBFIELDS BY INSTITUTION

$F T=F U L L$ TIME

PT = PART TIME

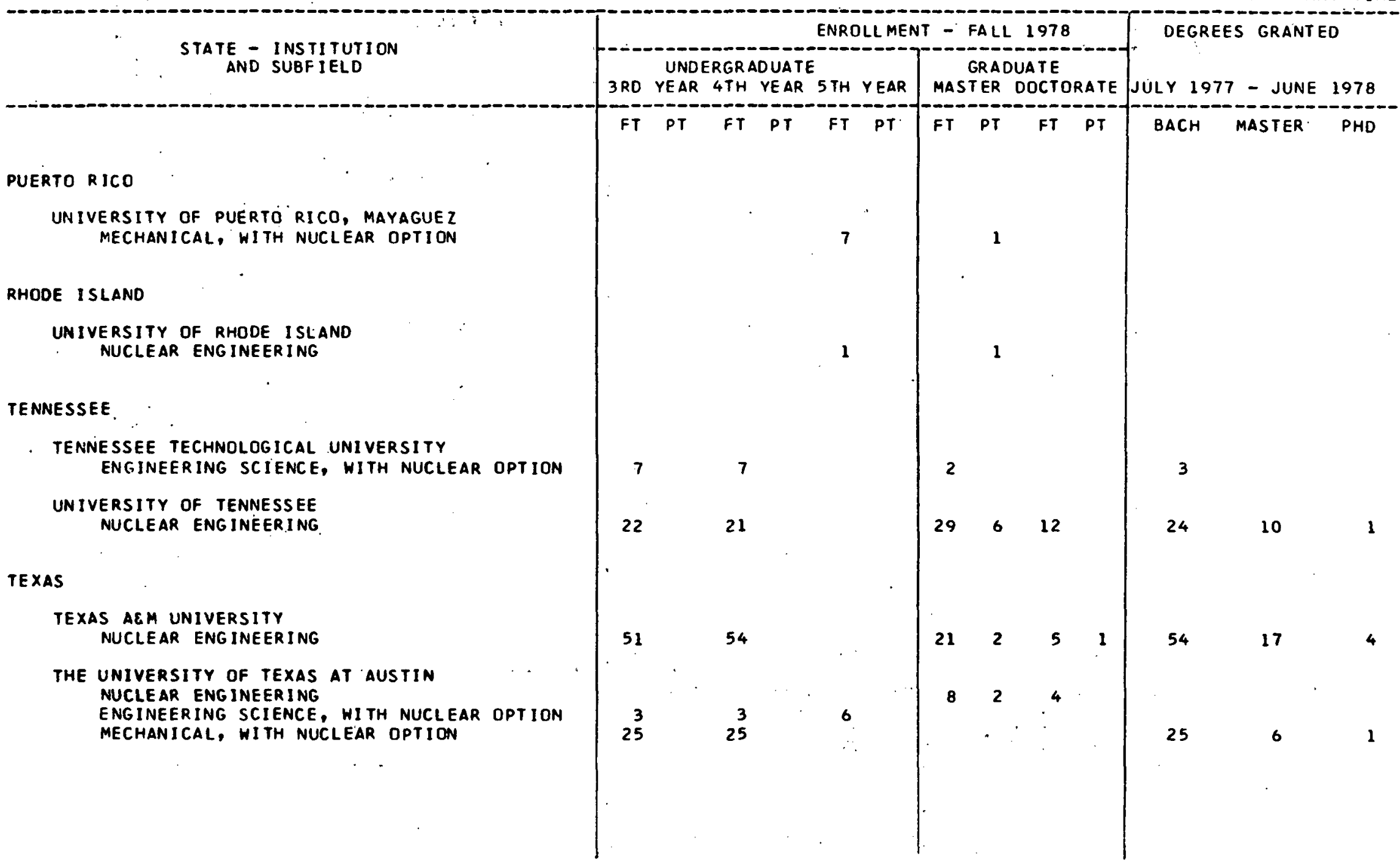

TENNESSEE

NESE TECHNOLOGICAL UN

ERSITY OF TENNESSEE

UNIVERSITY OF TEXAS AT AUSTIN

NUCLEAR ENGINEERING

NUCLEAR ENGINEERING 
APPENDIX A-2 (CONTINUED)

NUCLEAR ENGINEERING

ENROLLMENTS AND DEGREES IN SUBFIELOS BY INSTITUTION

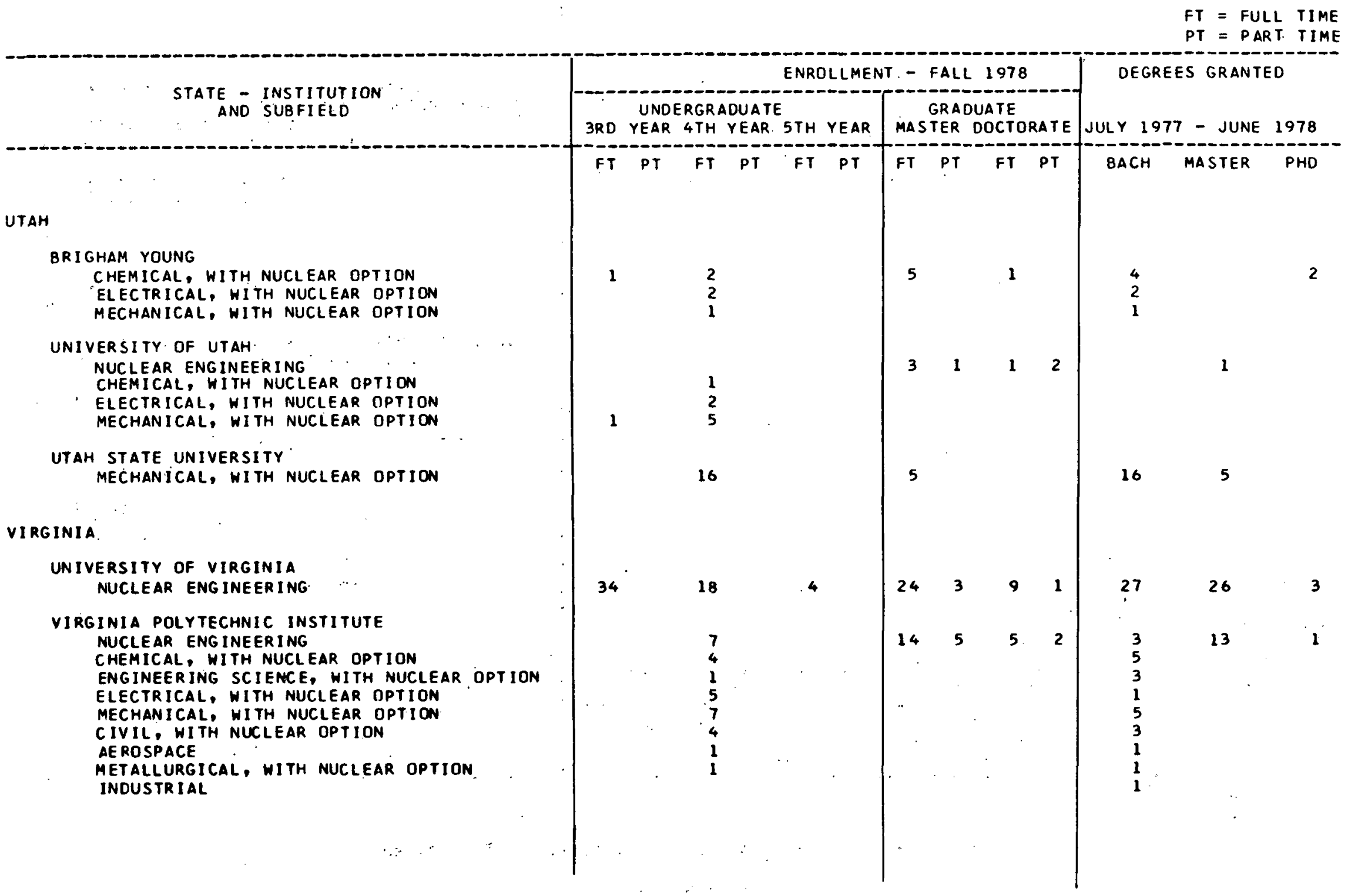


APPENDIX A-2 (CONTINUEO)

NUCLEAR ENGINEER ING

ENROLLMENTS AND OEGREES IN SUBF IELDS BY INSTITUTION

$F T=$ FULL TIME

PT = PART TIME

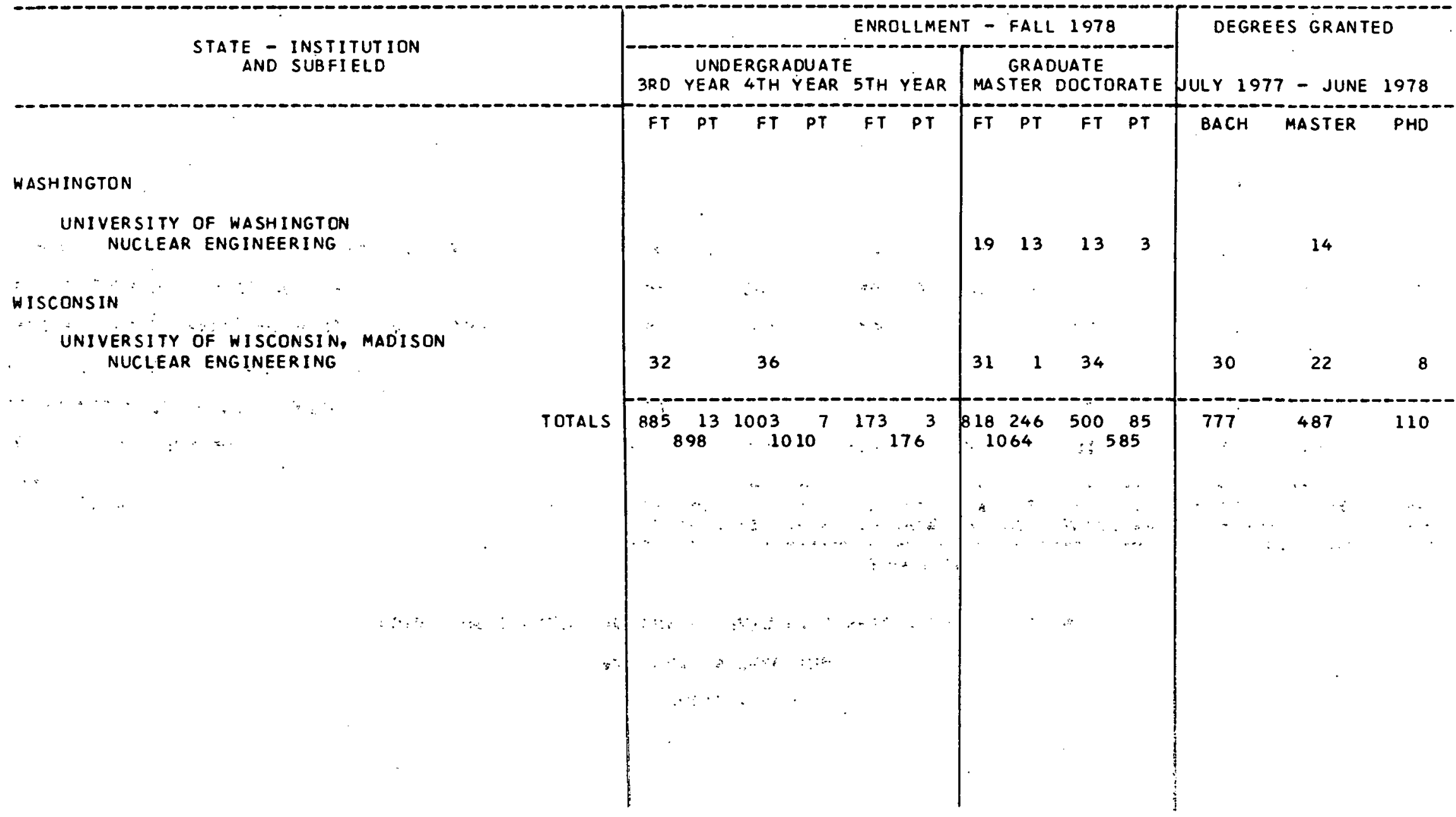


APPENDIX $A-3$

NUCLEAR ENGINEERING

NUMBER OF DEGREES AND ENROLLMENTS BY SUBFIELD IN FALL 1978

CURRICULUM

NUCLEAR ENGINEERING

CHEMICAL, WITH NUCLEAR OPTION

ELECTRICAL, WITH NUCLEAR OPTION

ENGINEERING SCIENCE, WITH'NUCLEAR OPTION

MECHANICAL, WITH NUCLEAR OPTION

OTHER ENG INEERING, WITH NUCLEAR OPTIONS

\begin{tabular}{|c|c|c|c|c|c|c|c|c|c|c|c|c|}
\hline & & . & & ENRT & ILLME & IT & & & & & DEGREES & \\
\hline $\begin{array}{r}\text { 3RD } \\
\text { FT }\end{array}$ & $\begin{array}{c}\text { YEAR } \\
\text { PT }\end{array}$ & $\begin{array}{r}4 T H \\
F T\end{array}$ & $\begin{array}{l}\text { YEAR } \\
\text { PT }\end{array}$ & $\begin{array}{l}5 T H \\
F T\end{array}$ & $\begin{array}{l}\text { YEAR } \\
\text { PT }\end{array}$ & $\begin{array}{l}\text { MAS } \\
\text { FT }\end{array}$ & $\begin{array}{r}\text { TER } \\
\text { PT }\end{array}$ & $\begin{array}{c}\text { DOCI } \\
\text { FT }\end{array}$ & $\begin{array}{c}\text { ORA TE } \\
\text { PT }\end{array}$ & $\mathrm{BACH}$ & MASTER & PHD \\
\hline-- & -- & - & - & -- & -- & - & -- & - & - & $-\infty$ & $-\infty-\infty$ & --- \\
\hline 626 & .9 & 649 & & 122 & 2. & 787 & 234 & 491 & .84 & 543 & 463 & 104 \\
\hline 19 & . & 32 & & 2 & & 5 & & 2 & & 33 & & 2 \\
\hline 51 & 2 & 54 & & 10 & & 3 & 3 & 3 & & 51 & 1 & 1 \\
\hline 37 & & 66 & & 19 & & 1 & & 1 & & 30 & 3 & \\
\hline 102 & & 131 & & 10 & 1 & 21 & 9 & 3 & 1 & 89 & 20 & 3 \\
\hline 50 & 2 & 71 & 7 & 10. & & 1 . & & & & 31 & & \\
\hline
\end{tabular}


APPENDIX $A-4$

NUCLEAR ENGINEERING

MINORITIES, WOMEN AND FOREIGN NATIONALS

FULL TIME

$P T=$ PART TIME

STATE - INSTITUTION

ENROLLMENT - FALL 1978

DEGREES GRANTED

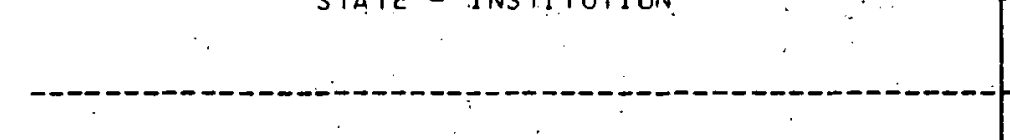

$\triangle L A B A M A$

TUSKEGEE INSTITUTE

FOREIGN NATIONAL MALES

BLACK MALES, U. S. CITIZENS

ARI ZONA

ARIZONA STATE UNIVERSITY

FORE IGN NATIONAL FEMALES

WHITE FEMALES, U. S. CITIZENS

UNIVERSITY OF ARIZONA

FORE IGN NATIONAL MALES

FORE IGN NATIONAL FEMALES

WHJTE FEMALES, U. S. CITIZZENS

BLACK MALES, $U$. S. CITIZENS

SPANI SH-SURNAMED MALES; U. S. CITIZENS

SPANI SH-SURNAMED FEMALES, U. S CITIZENS

ASIAN AMERICAN MALES, $U$. S. CITIZENS

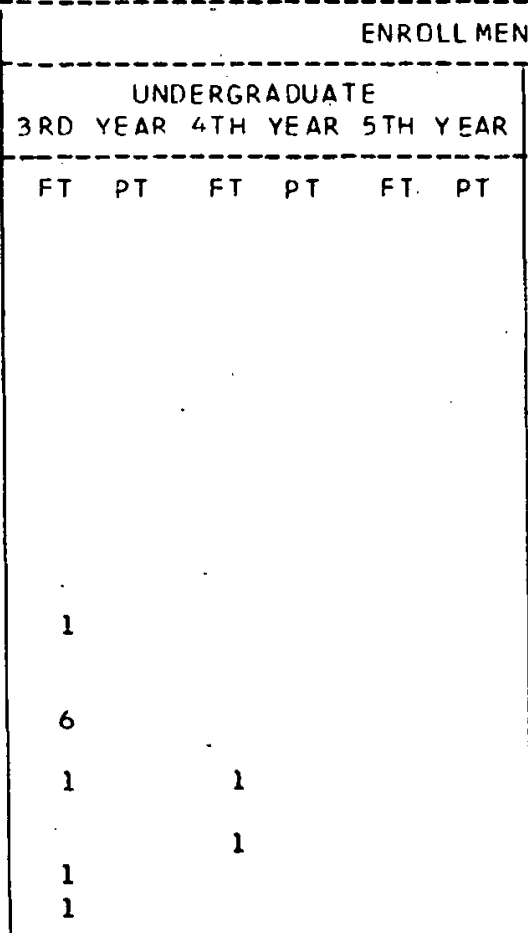

\begin{tabular}{c} 
GRADUATE \\
MASTER DOCTORATE \\
\hline FT PT JULY $1977-$ JUNE 1978 \\
\hline FT PT
\end{tabular}

CALIFORN IA

UNIVERSITY OF CALIFORNIA, BERKELEY FORE IGN NATIONAL MALES

FOREIGN NATIONAL FEMALES

WHITE FEMALES, U. S. CITIZENS

SPANI SH-SURNAMED MALES, U. S CITIZENS

ASIAN AMERICAN MALES, U. S. CITIZENS

UNIVERSITY OF CALIFORNIA, LOS ANGELES

FORE IGN NATIONAL MALES

FORE IGN NATIONAL FEMALES

WHITE FEMALES, U. S. CITIZENS

SPANISH-SURNAMED MALES, U. S. CITIZENS

ASIAN AMERICAN MALES, U. S. CITIZENS

ASIAN AMERICAN FEMALES, U. S. CITIZENS 
APPEND IX A-4 (CONT INUED)

NUCLEAR ENGINEERING

MINORITIES, WOMEN AND FORE IGN NATIOMALS

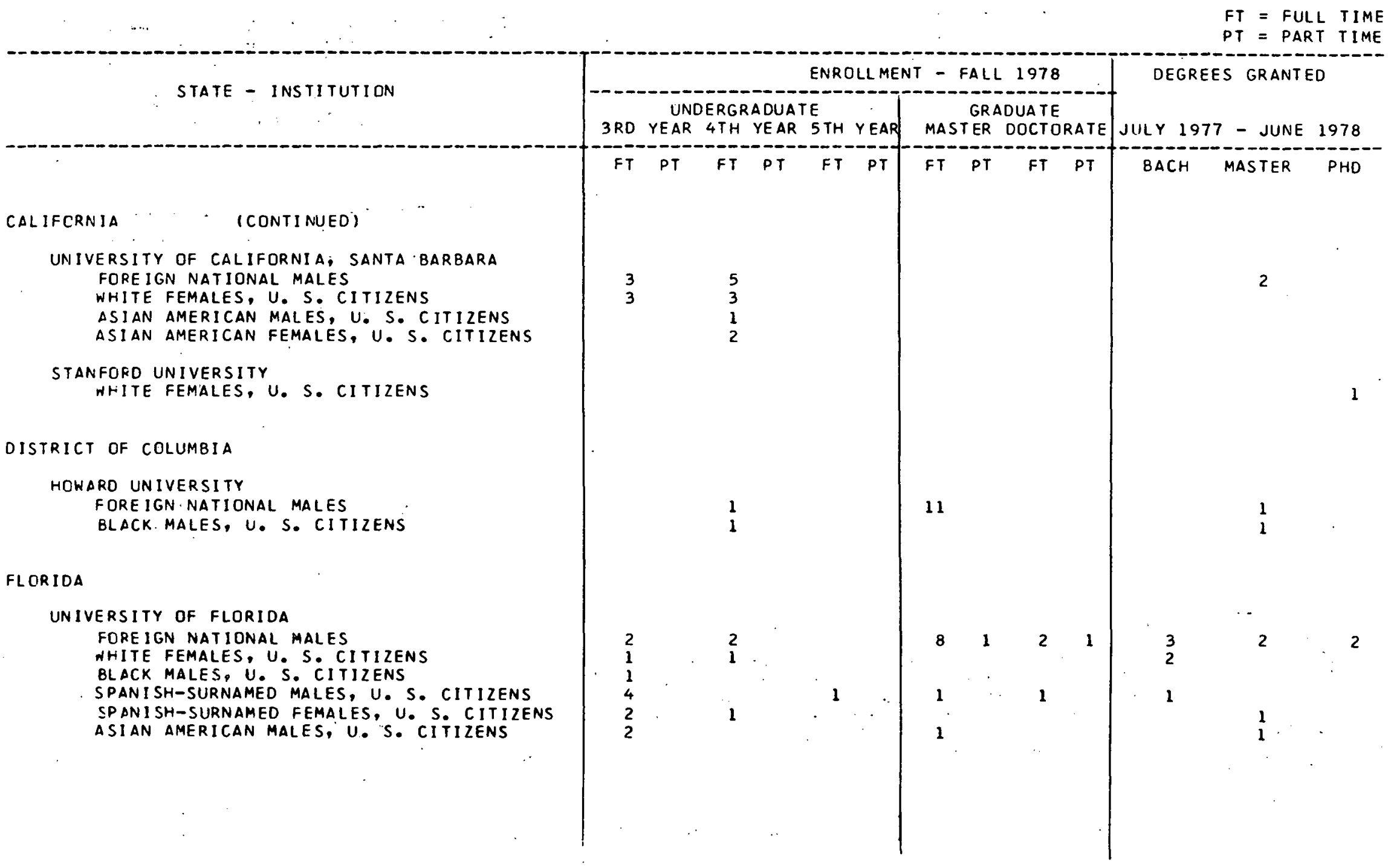




\section{APPENDIX A-4 (CONT INUED)}

NUCLEAR ENGINEERING

MINORITIES. WOMEN AND FORE IGN NATIONALS

FT = FULL TIME

PT = PART TIME

STATE - INSTITUTION

ENROLLMENT - FALL 1978

DEGREES GRANTED

-

GEORG IA

GEORG IA INSTITUTE OF TECHNOLOGY FORE IGN NATIONAL MALES WHITE FEMALES, U. S. CITIZENS BLACK MALES, U: S. CITIZENS BLACK FEMALES, U. S. CITIZENS SPANISH-SURNAMED MALES, U. S. CITIZENS

wू IDAHO

IDAHO STATE UNIVERSITY FOREIGN NATIONAL MALES WHITE FEMALES, U. S. CITIZENS

UNIVERSITY OF IDAHO

FORE IGN NATIONAL MALES

WHITE FEMALES, U. S. CITIZENS

ILLINOIS

NORTHWE STERN UNIVERSITY FORE IGN NATIONAL MALES WHITE FEMALES, U. S. CITIZENS

UNIVERSITY OF ILLINOIS

FORE IGN NATIONAL MALES

FOREIGN NATIONAL FEMALES

WHITE FEMALES, U. S. CITIZENS

BLACK MALES, U. S. CITIZENS

ASI AN AMERICAN MALES, U. S. CITIZENS

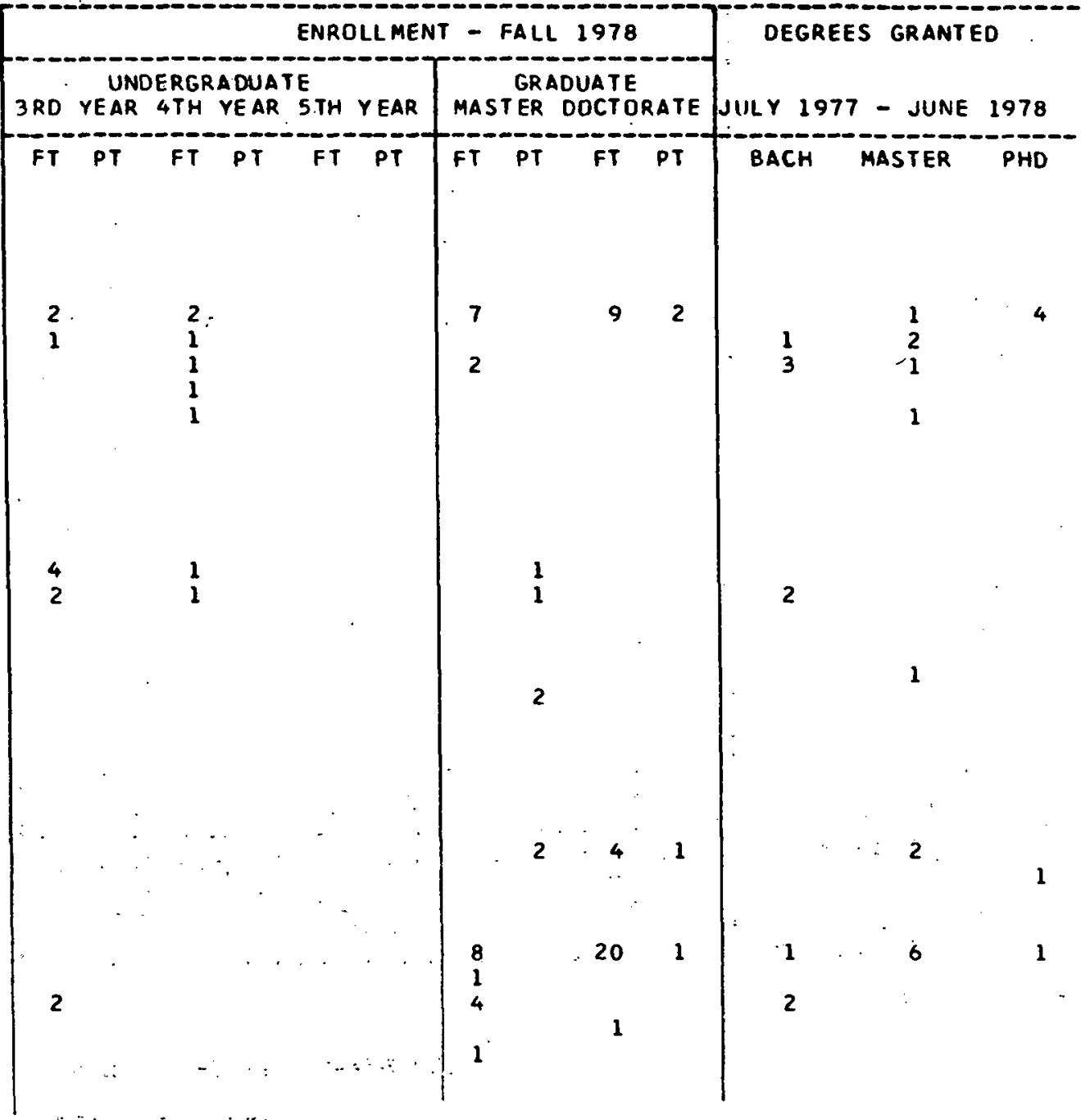


APPENDIX A-4 (CONT INUEO)

NUCLEAR ENGINEERING

MINORITIES, WOMEN AND FOREIGN NATIONALS

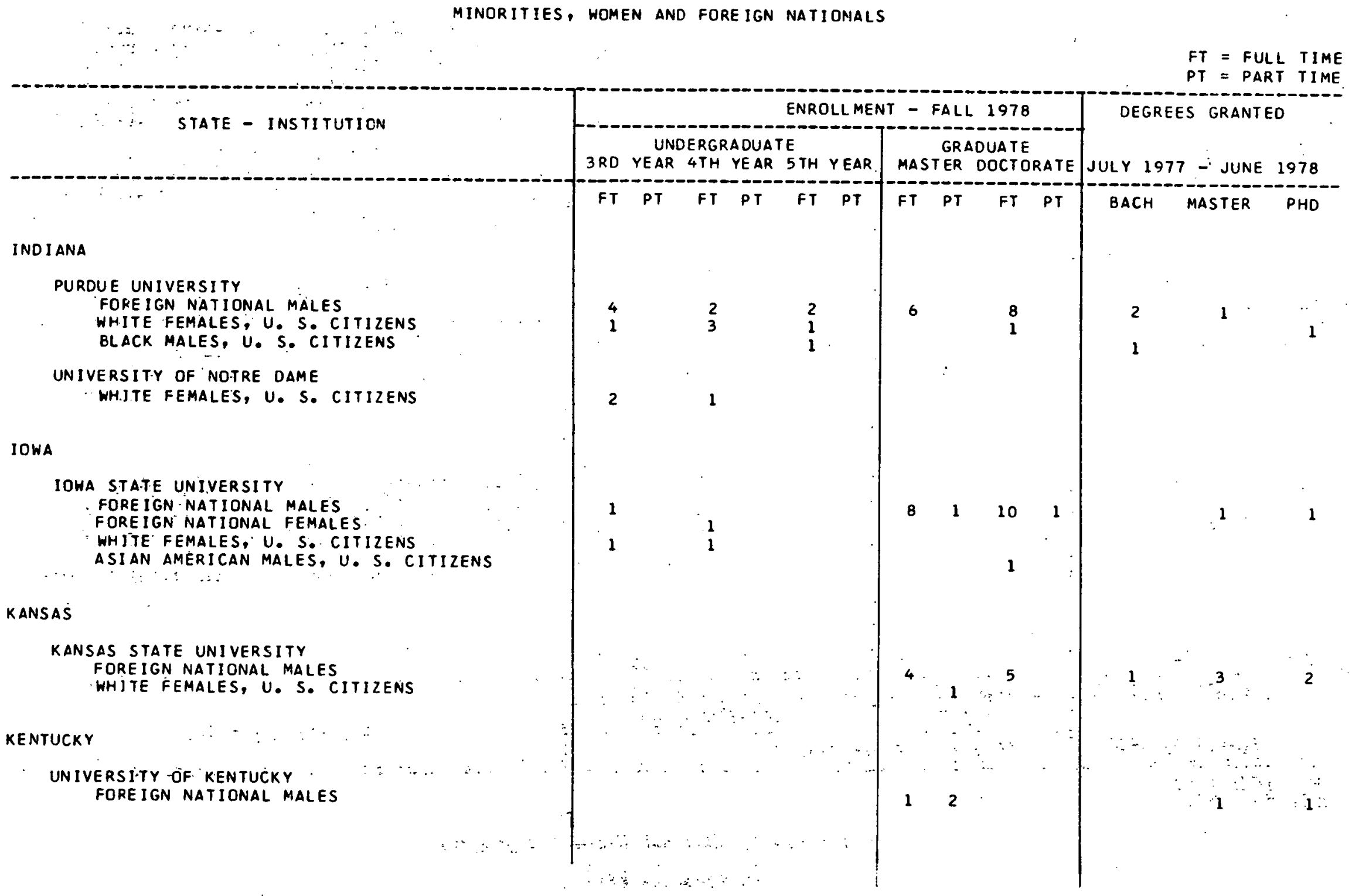


APPENDIX A-4 (CONTINUED)

NUCLEAR ENGINEER ING

MINORITIES, WOMEN AND FOREIGN NATIONALS

$F T=F U L L$ TIME
PT $=$ PART TIME

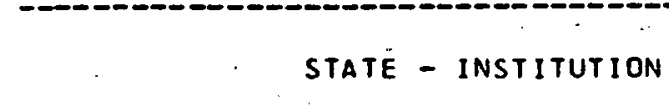

ENROLLMENT - FALL 1978

DEGREES GRANTED

-
-

LOUISI.ANA

LOUISI ANA STATE UNIVERSITY FORE IGN NATIONAL MALES

SPANISH-SURNAMED MALES, U. S. CITIZENS

MARYLAND

UNIVERSITY OF MARYLAND

FORE IGN NATIONAL MALES

FORE IGN NATIONAL FEMALES

WHJTE FEMALES, U. S. CITIZENS

BLACK MALES, U. S. CITIZENS

ASIAN AMERICAN MALES, U. S. CITIZENS

ASIAN AMERICAN FEMALES, $U . S$. CITIZENS

MASSACMUSETTS

MASSACHUSETTS INSTITUTE OF TECHNOLOGY

FOREIGN NATIONAL MALES

FORE IGN NATIONAL FEMA

WHITE FEMALES, U. S. CITIZENS

BLACK MALES, $U$. S. CITIZENS

SPANISH-SURNAMED MALES, U. S.- CITIZENS

ASIAN AMERICAN MALES, U. S. CITIZENS

UNIVERSITY OF LOWELL

FORE IGN NATIONAL MALES

WHITE FEMALES, U. S. CITIZENS

SPANISH-SURNAMED MALES, U. S. CITIZENS

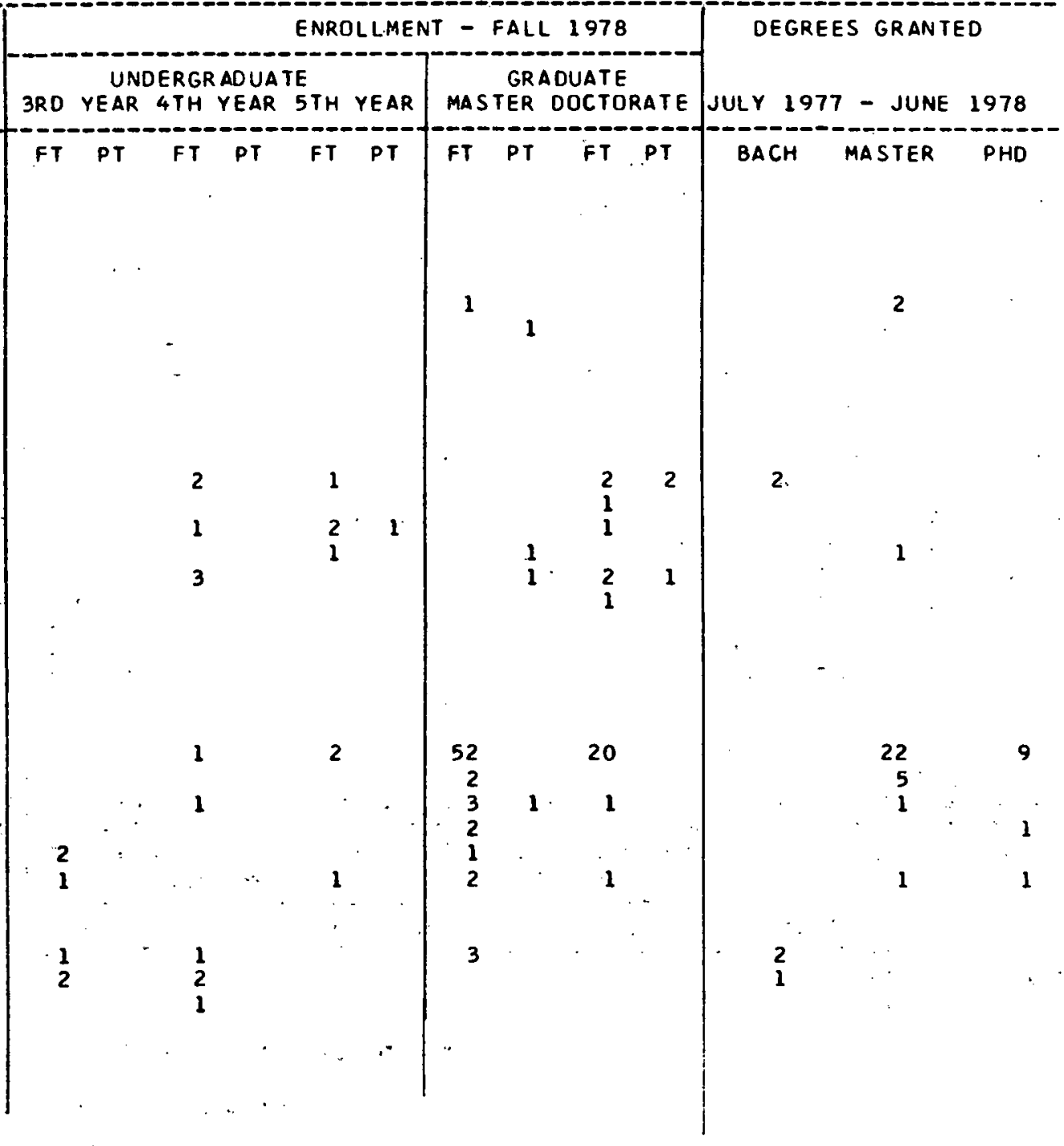


APPENDIX A-4 (CONTINUED)

NUCLEAR ENGINEER ING

MINORITIES, WOMEN ANO FOREIGN NATIONALS

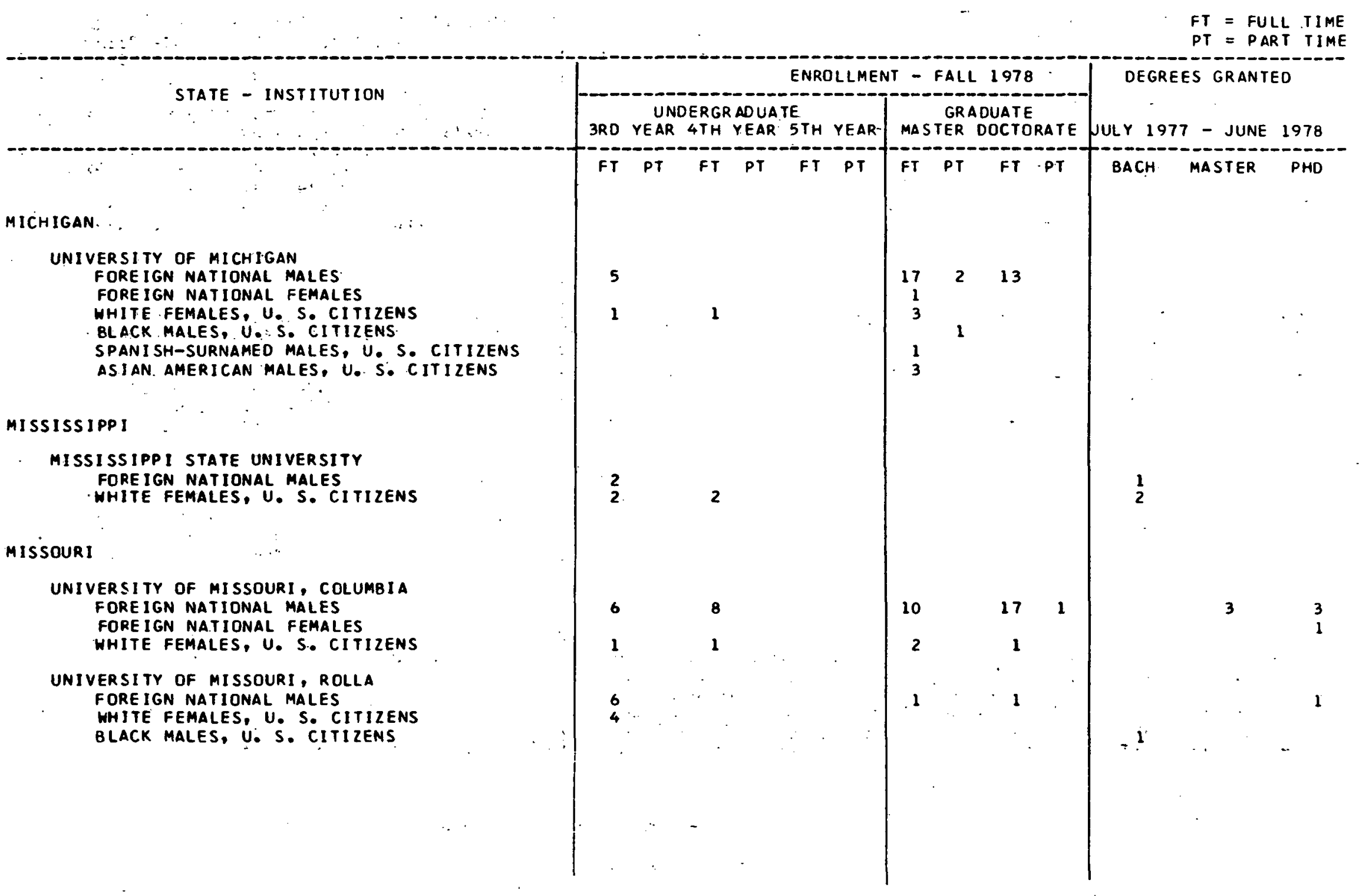


APPENDIX A-4 (CONT INUED)

NUCLEAR ENG INEERING

MINORITIES, WOMEN AND FOREIGN NATIONALS

$F T=F U L L$ TIME

PT = PART TIME

...

$\because \quad \because$ STATE - INSTITUTIION

ENROLLMENT - FALL 1978 DEGREES GRANTED

NEW JERSEY

NEW JERSEY INSTITUTE OF TECHNOLOGY FORE IGN NATIONAL MALES

FORE IGN NATIONAL FEMALES

WHITE. FEMALES, U. S० CITIZENS

SPANISH-SURNAMED MALES, U. S. CITIZENS

ASIIAN AMERICAN MALES, U. S. CITIZENS

NEW MEXICO

UNIVERSITY OF NEW MEXICO

FÓRE IGN NATIONAL MALES

SPANI SH-SURNAMED MALES, U. S. CITIZENS

ASIAN AMERICAN MALES, U. S. CITIZENS

NEW YORK.

CLARKSON COLLEGE OF TECHNOLOGY WHITE FEMALES, U. S. CITIZENS

BLACK MALES, $U$. S. CITIZENS

SPANI SH-SURNAMED MALES, U. S. CITIZENS

COLUMBIA UNIVERSITY

FORE IGN NATIONAL MALES

FOREIGN NATIONAL FEMALES

WHITE FEMALES, U. S. CITIZENS

BLACK MALES, U. S. CITIZENS

SPANISH-SURNAMED MALES, U. S. CITIZENS

ASIAN AMERICAN MALES, U. S. CITIZENS

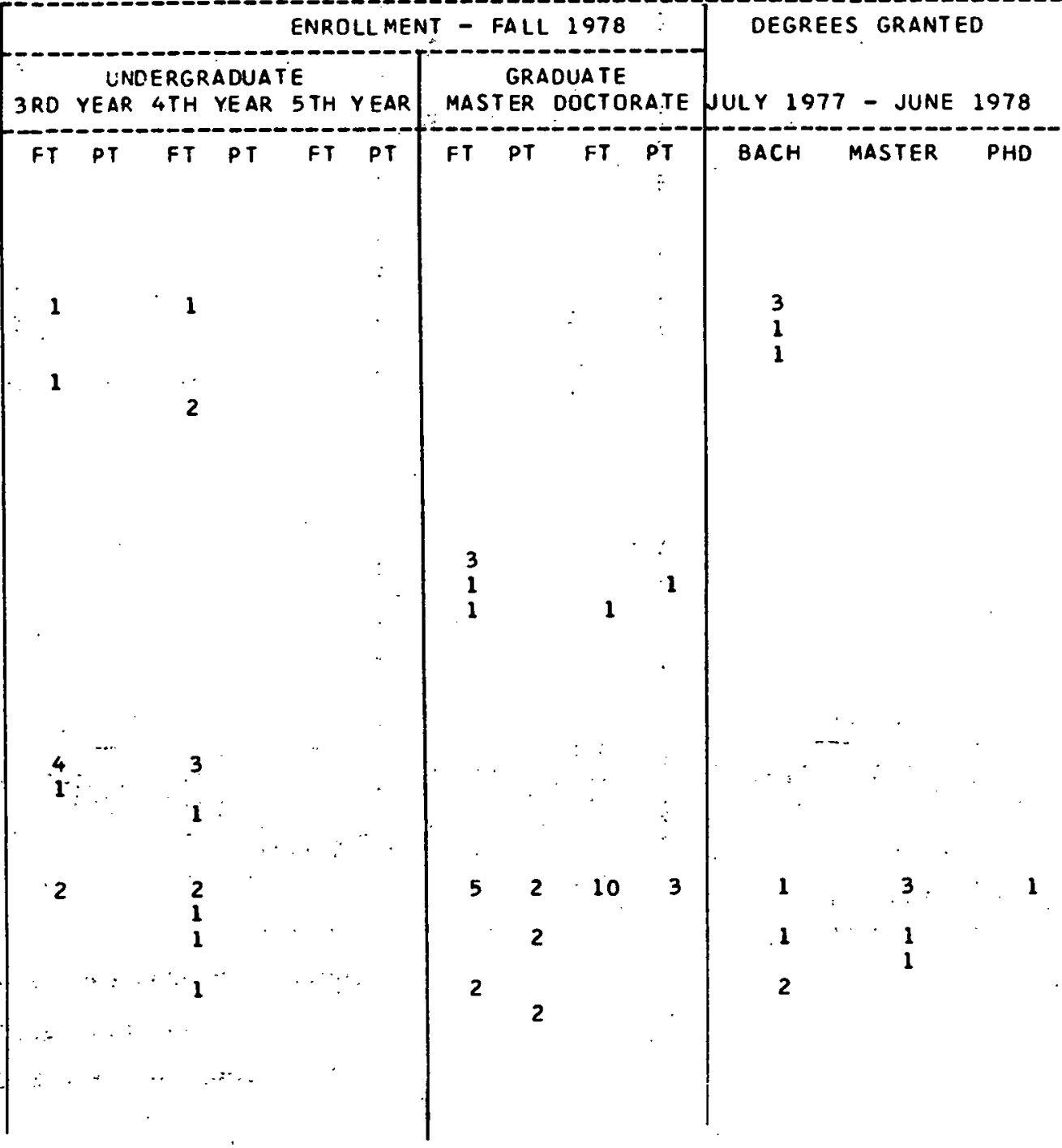


APPENDIX A-4 (CONT INUED)

NUCLEAR ENGINEERING

MINORITIES, WOMEN ANO FOREIGN. NATIONALS

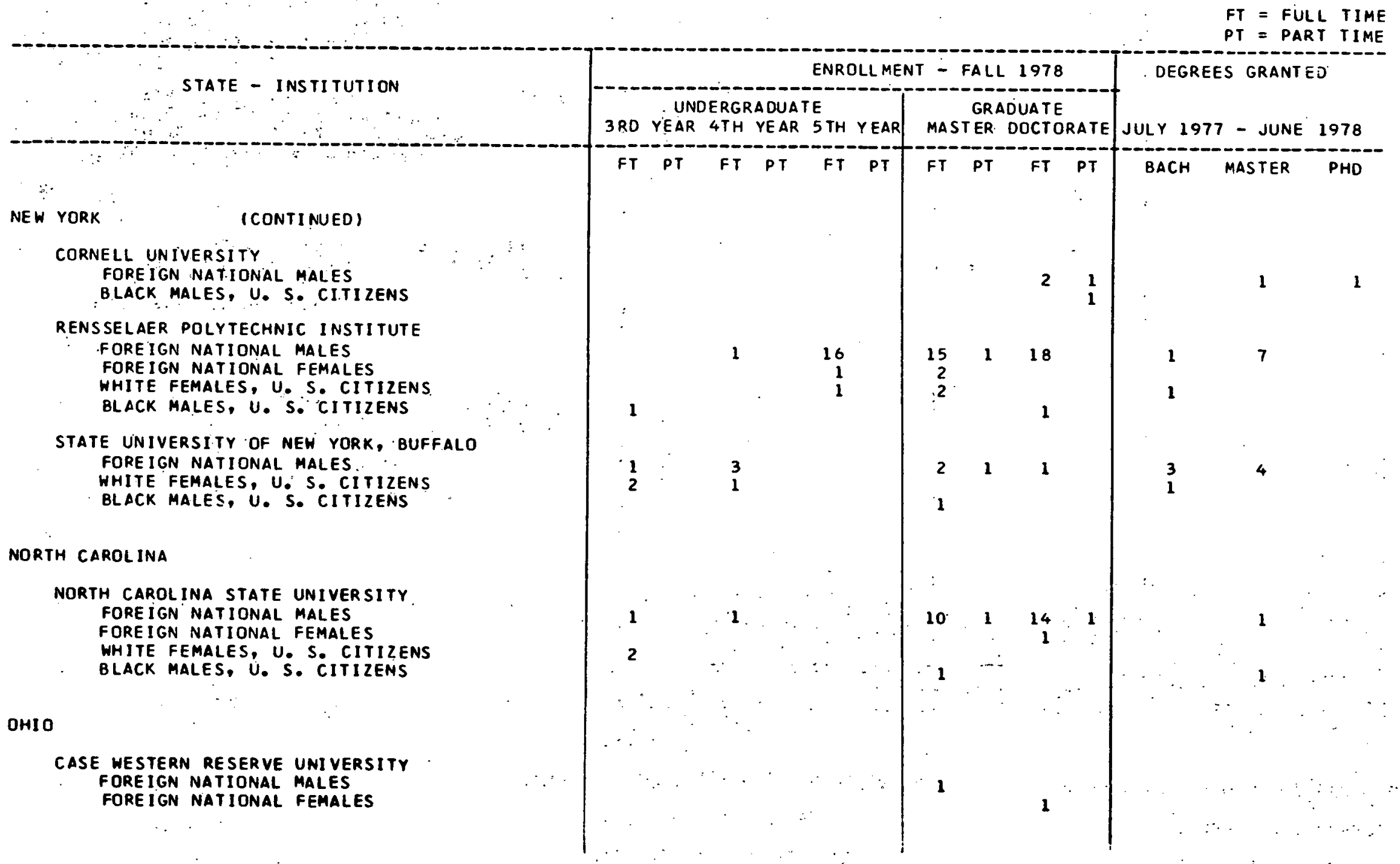


APPENDIX A-4 (CONTINUED)

NUCLEAR ENGINEER ING

MINORITIES, WOMEN AND FOREIGN NATIONALS

$F T=$ FULL TIME

$P T=P A R T$ TIME

STATE - INSTITUTION

ENROLLMENT - FALL 1978

OEGREES GRANTED

-

OHIO

(CONT INUEEO)

DHIO STATE UNIVERSITY

FORE IGN NATIONAL MALES

WHITE FEMALES, U. S. CITIZENS

OK LAHOMA

UNIVERSITY OF OKLAHOMA

FORE IGN NATIONAL MALES

WHITE FEMALES, U. S. CITIZENS

ASIAN AMERICAN MALES, U. S. CITIZENS

OREGON

OREGON STATE UNIVERSITY

FORE IGN NATIONAL. MALES

FOREIGN NATIONAL FEMALES

WHITE FEMALES, U. S. CITIZENS

BLACK MALES, U. $S$. CITIZENS

ASIAN AMERICAN MALES, U. S. CITIIZENS

PENNSYLVANIA

CARNEGIE-MELLON UNIVERSITY.

FORE IGN NATIONAL MALES

WHITE FEMALES, U. S. CITIZENS

PENNSYLVANIA STATE UNIVERSITY FOREIGN NATIONAL MALES

WHITE FEMALES, U. S. CITIZENS

BLACK MALES, $U$. S. CITIZENS

ASIAN AMERICAN MALES, U. 5. CITIZENS

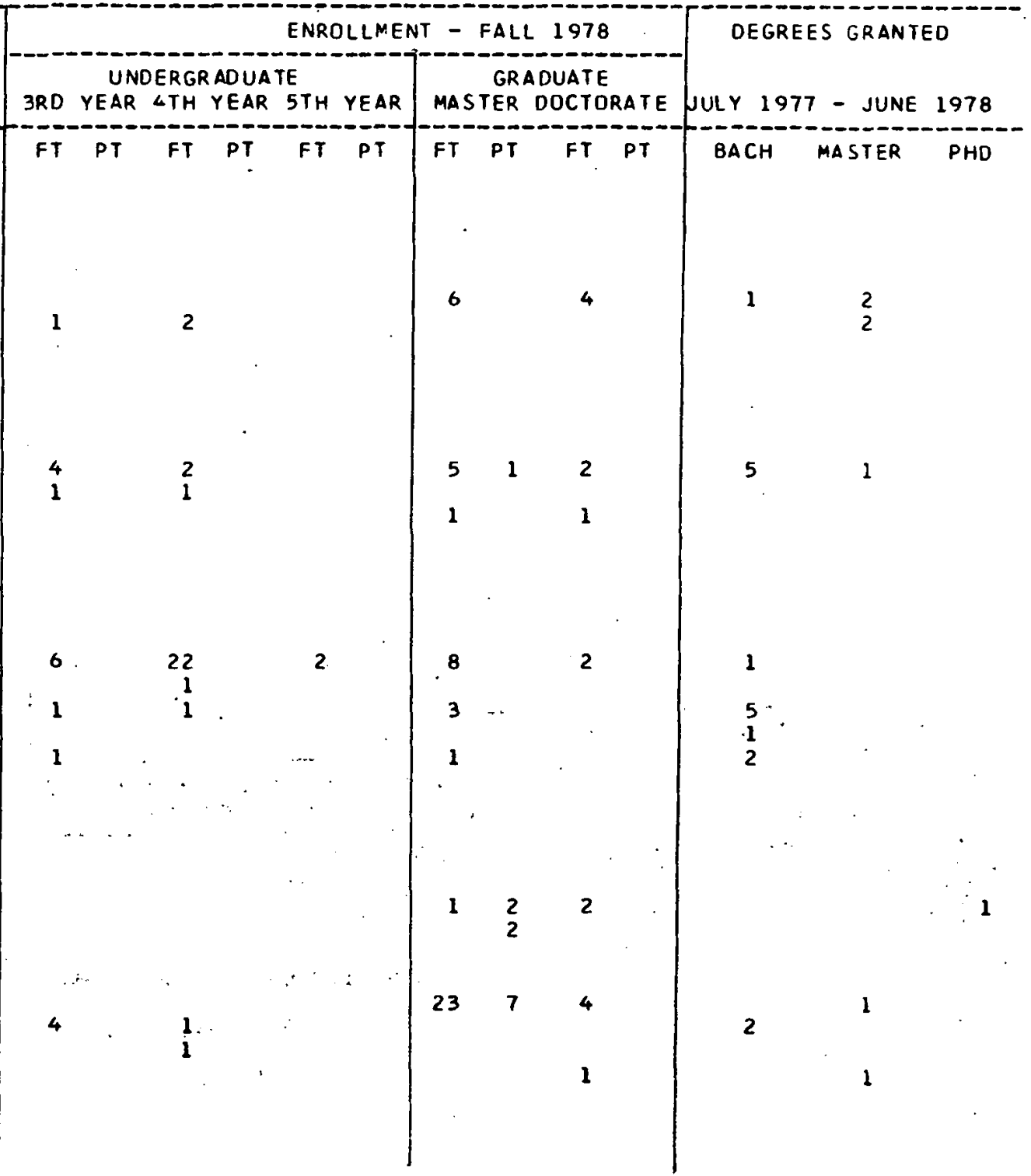


APPENDIX A-4 (CONTINUED)

NUCLEAR ENGINEER ING

MINORITIES, WOMEN AND FOREIGN NATIONALS

$T=$ FULL TIME

$P T=P A R T$ TIME

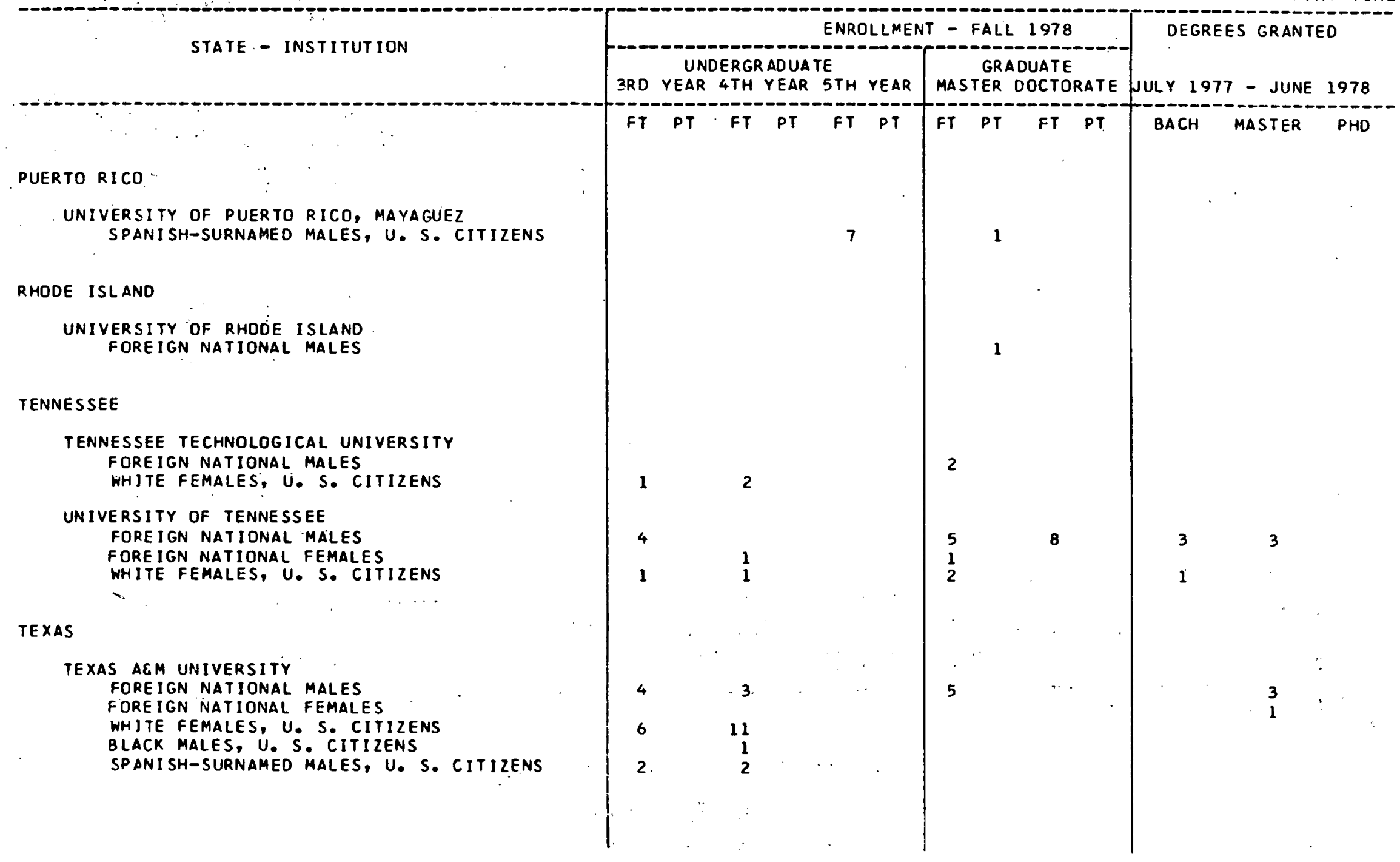


APPENDIX A-4 (CONTINUED)

NUCLEAR ENGINEER ING

MINORITIES, WOMEN AND FOREIGN MATIOMALS

T = FULL TIME

PT = PART TIME

STATE - INSTITUTION

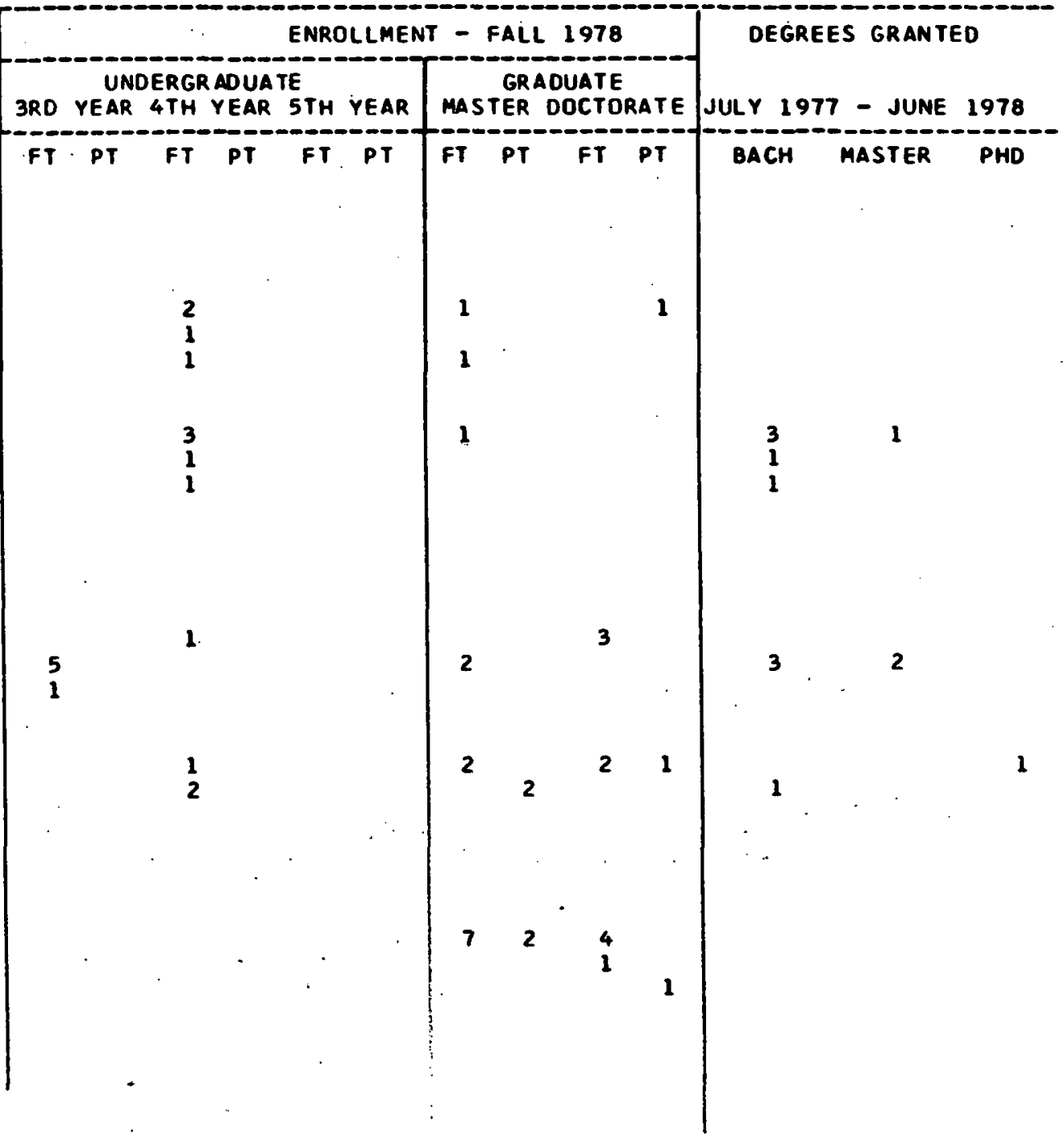

UNIVERSITY OF UTAH

FORE IGN NATIONAL MALES.

WHJTE FEMALES, U. S. CITIZENS

ASIAN AMERICAN MALES, U. S. CITIZENS

UTAH STATE UNIVERSITY

FOREIGN NATIONAL MALES

BLACK MALES, $U$. S. CITIZENS

$\nRightarrow$

ASIAN AMERICAN MALES, U. S. CITIZENS

VIRG INIA

UNIVERSITY OF VIRGINIA

FORE IGN NATIONAL MALES

WHITE FEMALES, U. S. CITIZENS

BLACK MALES, U. S. CITIZENS

VIRGINIA POLYTECHNIC INSTITUTE

FOREIGN NATIONAL MALES

WHITE FEMALES, U. S. CITIZENS

WASHINGTON

UNIVERSITY OF HASHINGTON

FOREIGN NATIONAL MALES

HHITE FEMALES, U. S. CITIZENS

BLACK MALES, U. S. CITIZENS 
APPENDIX A-4 (CONTINUED)

NUCLEAR ENGINEER ING

MINORITIES, WOMEN AND FOREIGN NATIONALS

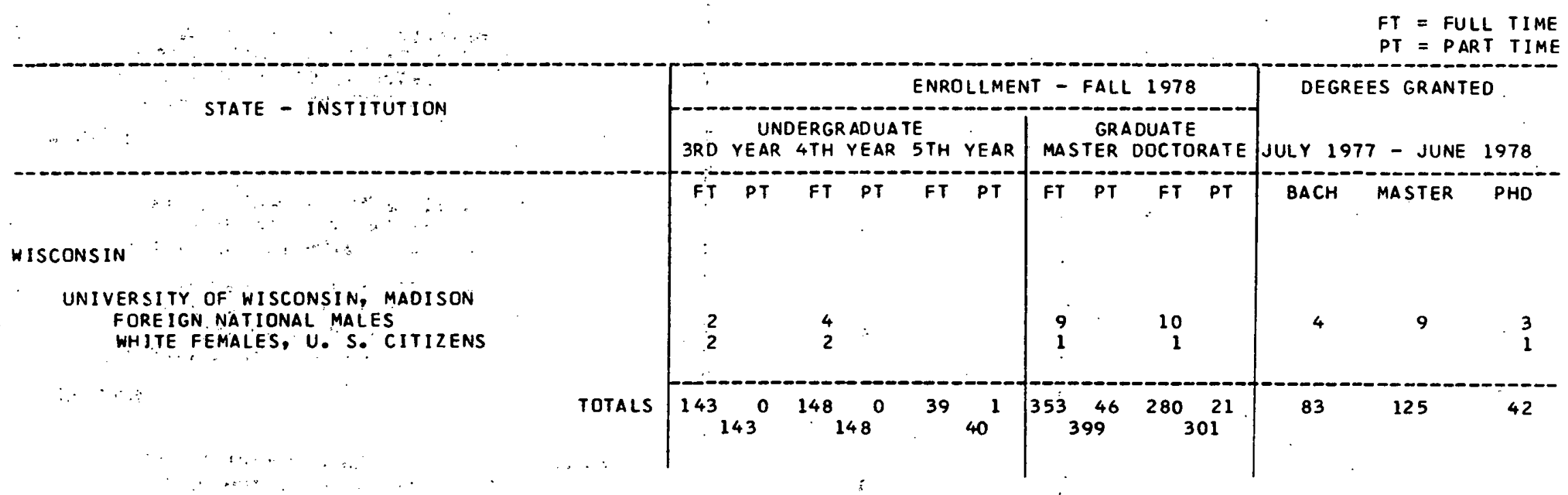


APPENDIX A-5

NUCLEAR ENGINEERING CURRICULUM

OR OPTIONS BY UNDERGRADUATE OR GRADUATE INSTITUTION

FALL 1978

NUCLEAR ENGINEERING

\section{UNDERGRADUATE}

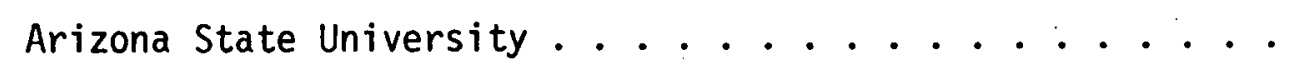

University of Arizona.

University of California, Santa Barbara . . . . . . . .

University of Florida. . . . . . . . . . . . . . .

Georgia Institute of Technology. . . . . . . . . . . .

University of Illinois . . . . . . . . . . . . . . . . . .

Purdue University. • . . . . . . . . . . . . . . . . . . .

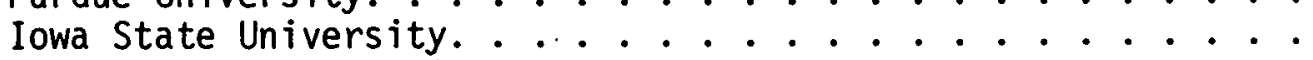

Kansas State University. . . . . . . . . . . . . . . . . .

University of Maryland ...................

Massachusetts Institute of Technology. .......... . . . . . .

University of Lowell. . . . . . . . . . . . . . . . .

University of Michigan.

Mississippi State University .

University of Missouri, Rolla.

Columbia University.

Polytechnic Institute of New York.

Rensselaer Polytechnic Institute . . . . . . . . . . .

State University of New York, Buffalo. . . . . . . . . .

\section{GRADUATE}

Arizona State University

Tuskegee Institute

University of Arizona

University of California, Berkeley

University of California, Los Angeles

University of California, Santa Barbara

University of Florida

Georgia Institute of Technology

Idaho State University

University of Idaho

Northwestern University

University of Illinois

Purdue University

Iowa State University

Kansas State University

Louisiana State University

University of Maryland

Massachusetts Institute of Technology

University of Lowell

University of Michigan

Mississippi State University

University of Missouri, Columbia

University of Missouri, Rolla

University of New Mexico

Columbia University

Cornell University

Polytechnic Institute of New York

Rensselaer Polytechnic Institute

State University of New York, Buffalo 
APPENDIX A-5 (Continued)

NUCLEAR ENGINEERING CURRICULUM

OR OPTIONS BY UNDERGRADUATE OR GRADUATE INSTITUTION

FALL 1978

UNDERGRADUATE

North Carolina State University. . . . . . . . . . North Carolina State University

Air Force Institute of Technology

University of Cincinnati................ University of Cincinnati

Ohio State University

University of $0 \mathrm{klahoma}$

Oregon State University.

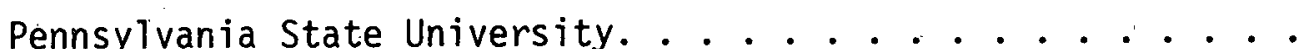

University of Rhode Island ................

University of Tennessee. . . . . . . . . . . . . . . .

University of OKlahoma

Oregon State University

Carnegie-Mellon University

Pennsylvania State University

University of Rhode Island

Universitv of Tennessee

Texas A\&M University.............. Texas A\&M University

University of Texas, Austin

University of Utah

University of Virginia .............. University of Virginia

Virginia Polytechnic Institute . . . . . . . . . Virginia Polytechnic Institute

University of Wisconsin. .............. University of Wisconsin

CHEMICAL WITH NUCLEAR OPTION

Arizona State University

University of Idaho

University of Maryland

Michigan Technical University

University of Missouri, Columbia

Clarkson College of Technology

Brigham Young University... . . . . . . . . . Brigham Young University

University of Utah

Virginia Polytechnic Institute

University of California, Santa Barbara 
APPENDIX A-5 (Continued)

NUCLEAR ENGINEERING CURRICULUM

OR OPTIONS BY UNDERGRADUATE OR GRADUATE INSTITUTION

FALL 1978

ENGINEERING SCIENCE WITH NUCLEAR OPTION

UNDERGRADUATE

GRADUATE

Arizona State University. .............. Arizona State University

Northwestern University

Louisiana State University

University of Maine

University of Maryland

New Jersey Institute of Technology

$\rightarrow \quad$ Ohio State University

State University of New York

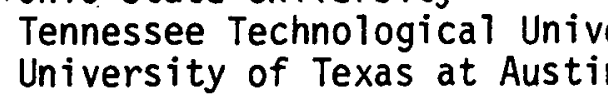

ELECTRICAL. WITH NUCLEAR OPTION

Arizona State University

University of California, Berkeley

University of Maryland

Worcester Polytechnic Institute

Michigan Technical University

University of Missouri, Columbia

New Jersey Institute of Technology

Clarkson College of Technology

Brigham Young University

Case Western Reserve University

University of Utah

Virginia Polytechnic Institute 
APPENDIX A-5 (Continued)

NUCLEAR ENGINEERING CURRICULUM

OR OPTIONS BY UNDERGRADUATE OR GRADUATE INSTITUTION

FALL 1978

MECHANICAL WITH NUCLEAR OPTION

\section{UNDERGRADUATE}

GRADUATE

Arizona State University. . . . . . . . . . . . Arizona State University

University of California, Berkeley Stanford University

Howard University

Colorado State University

University of Idaho

University of Notre Dame

E University of Maryland

Worcester Polytechnic Institute:

Michigan Technical University

University of Missouri, Columbia

New Jersey Institute of Technology

Clarkson College of Technology

Renesselaer Polytechnic Institute .......... Renesselaer Polytechnic Institute

Ohio State University

University of Pennsylvania. . . . . . . . . . . . University of Pennsylvania

University of Puerto Riço.............. University of Puerto Rico

South Dakota State University

University of Texas, Austin

Brigham Young University

University of Utah

Utah State University............... Utah State University

Virginia Polytechnic Institute

Purdue University

University of Kentucky.

Harvard University 


\section{APPENDIX A-5 (Continued) \\ NUCLEAR ENGINEERING CURRICULUM}

OR OPTIONS BY UNDERGRADUATE OR. GRADUATE INSTITUTION

FALL 1978

AEROSPACE

\section{UNDERGRADUATE}

Virginia Polytechnic Institute

AGRICULTURAL ENGINEERING

University of Maryland

APPLIED PHYSICS WITH NUCLEAR OPTION

G

Purdue University

ASTRONOMICAL ENGINEERING

University of Maryland

CIVIL WITH· NUCLEAR OPTION

University of California, Berkeley

Clarkson College of Technology

Virginia Polytechnic Institute

COMPUTER SCIENCE WITH NUCLEAR OPTION

New Jersey Institute of Technology

FIRE PROTECTION ENGINEERING

University of Maryland 
APPENDIX A-5 (Continued)

NUCLEAR ENGINEERING CURRICULUM

OR OPTIONS BY UNDERGRADUATE OR GRADUATE INSTITUTION

FALL. 1978 .

GENERAL WITH NUCLEAR OPTION

UNDERGRADUATE

$\ldots \ldots \ldots$ GRADUATE

Idaho State University

INDUSTRIAL WITH·NUCLEAR OPTION

University of California, Berkeley

Virginia Polytechnic Institute

INTERDISCIPLINARY ENGINEERING

I $\quad$ Purdue University.

MATERIALS SCIENCE

University of California, Berkeley

METALLURGICAL WITH NUCLEAR OPTION

University of Idaho

Michigan Technical University. . . . . . . . . . Michigan Technical University Virginia Polytechnic Institute

NUCLEAR ENGINEERING TECHNOLOGY

Oregon State University PHYSICAL SCIENCE

University of Maryland PHYSICS WITH NUCLEAR OPTION

University of Maine 
APPEND $1 \times A-6$

NUCLEAR ENGINEER.ING

ENROLLMENTS AND DEGREES IN SUBF IELDS BY STATE ANO REGION

$F T=F U L L ~ T I M E$

PT = PART TIME

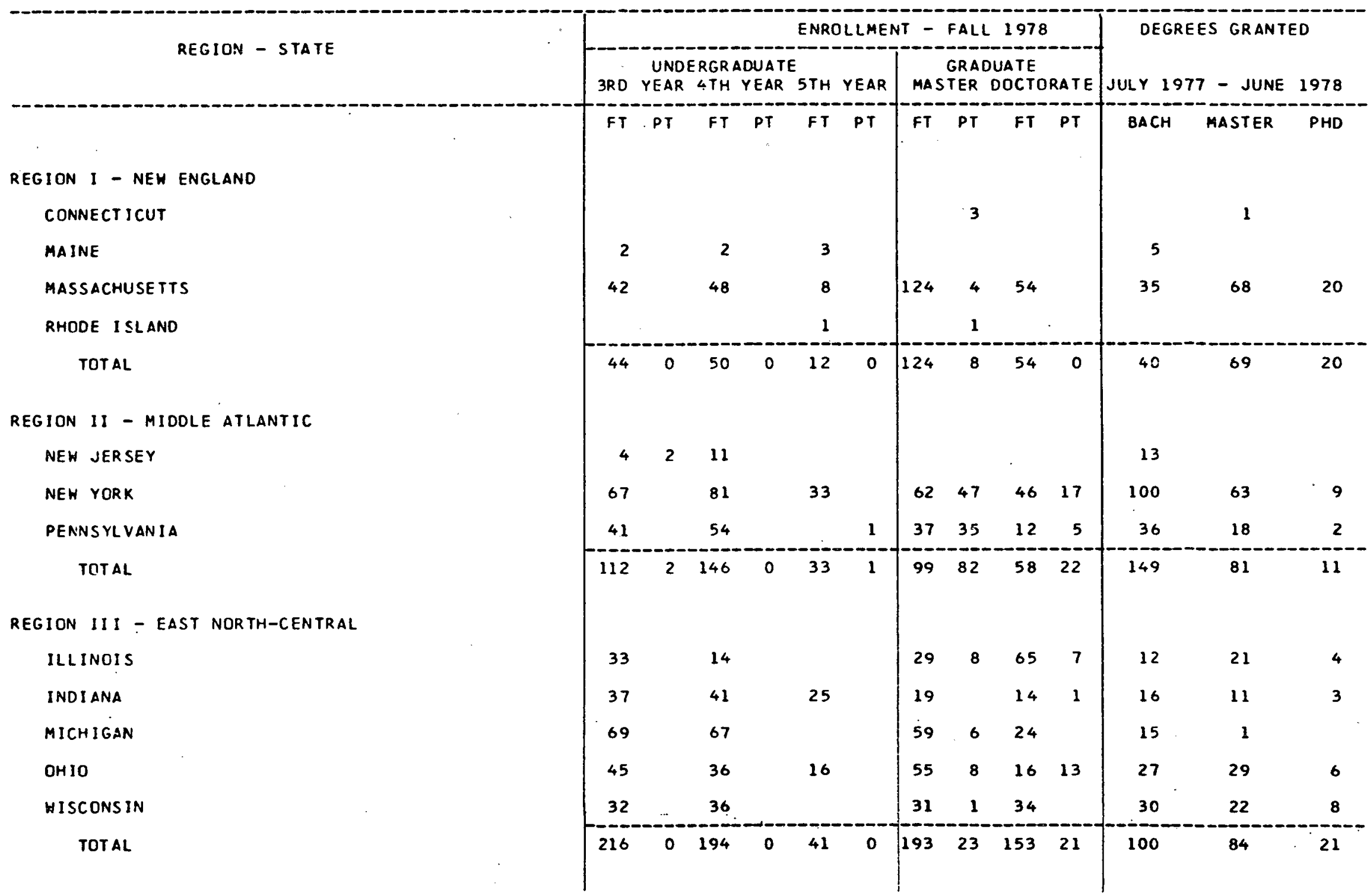




\section{APPENDIX A-6 (CONTINUED)}

NUCLEAR ENGINEERING

ENROLLMENTS ANO DEGREES IN SUBFIELDS BY STATE AND REGION

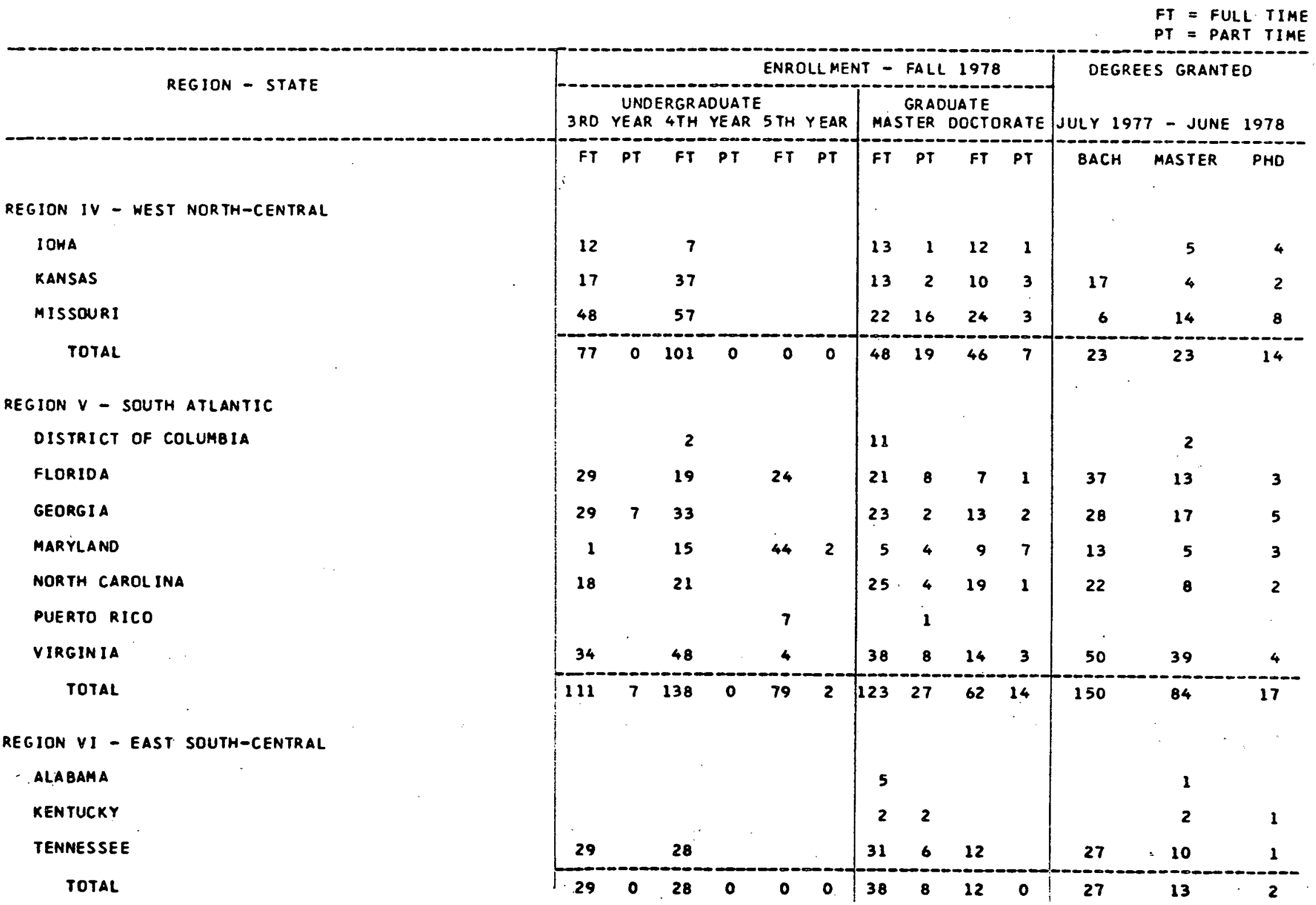


APPENDIX A-6 (CONTINUED)

NUCLEAR ENGINEER ING

ENROLLMENTS AND DEGREES IN SUBFIELDS BY STATE AND REGION

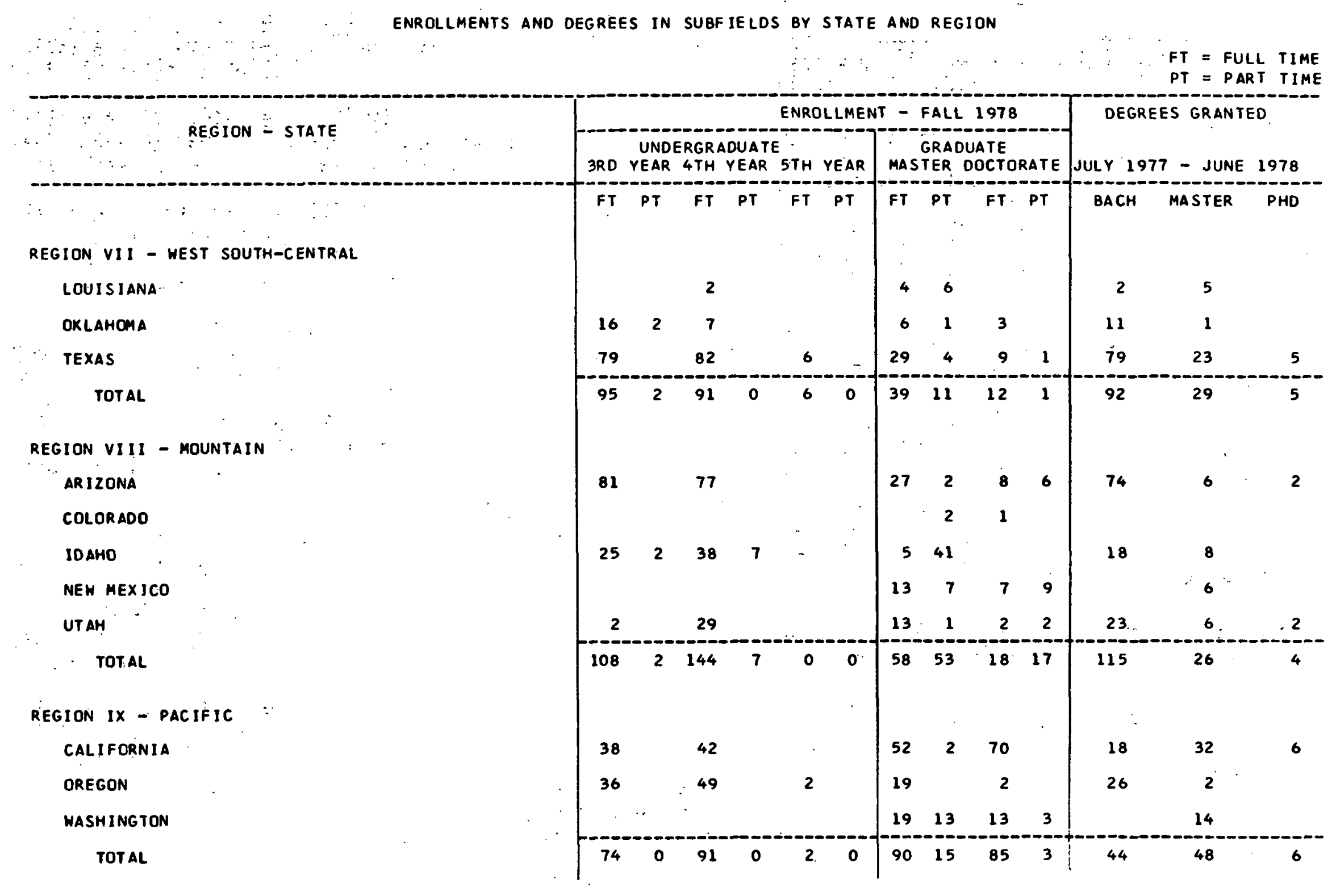


APPENDIX B-1

ADDRESSES OF INSTITUTIONS IN SURVEY UNIVERSE

WITH ACTIVE PROGRAMS

NUCLEAR ENGINEERING

Tuskegee. Institute

School of Engineering

Tuskegee, Alabama 36088

Arizona State University

Department of Engineering

Tempe, Arizona 85281

University of Arizona

Department of Nuclear Engineering

Tucson, Arizona 85721

Stanford University

Department of Mechanical Engineering

G

University of California, Berkeley

Department of Nuclear Engineering

Berkeley, California 94720

University of California, Los Angeles

Department of Chemical, Nuclear,

and Thermal Engineering

Los Angeles, California 90024

University of California, Santa Barbara

Department of Chemical \& Nuclear Engineering

Santa Barbara, California 93106

Colorado State University

Department of Mechanical Engineering

Fort Collins, Colorado 80523

Howard University

Department of Mechanical Engineering

Washington, D. C. 20059

University of Florida

Department of Nuclear Engineering Sciences

Gainesville, Florida 32611

Georgia Institute of Technology

School of Nuclear Egnineering

Atlanta, Georgia 30332

Idaho State University

School of Engineering

Pocatello, Idaho 83209

University of Idaho

Mechanical Engineering Department

Moscow, Idaho 83843

Northwestern University

Engineering Sciences \& Applied Math Department

Evanston, Illinois 60201

University of 111 inois

Department of Nuclear Engineering

Urbana, Illinois 61801

Purdue University

Department of Nuclear Engineering

West Lafayette, Indiana 47906

University of Notre Dame

Department of Aerospace \& Mechanical Engineering Notre Dame, Indiana 46556 
APPENDIX B-1 (Continued)

ADDRESSES OF INSTITUTIONS IN SURVEY UNIVERSE

WITH ACTIVE PROGRAMS

Iowa State University

NUCLEAR ENGINEERING

Department of Nuclear Engineering

Ames, Iowa 50011

Kansas Stàte University

Department of Nuclear Engineering

Manhattan, Kansas 66506

University of Kentucky

Department of Mechanical Engineering

Lexington, Kentucky 40506

Louisiana State University

Nuclear Science Center

Baton Rouge, Louisiana 70803

University of Maine

Department of Physics

Orono, Maine 04469

University of Maryland

Department of Chemical \& Nuclear Engineering

College Park, Maryland 20742

Massachusetts Institute of Technology

Department of Nuclear Engineering

Cambridge, Massachusetts 02139

University of Lowell

Department of Nuclear Engineering

Lowe11, Massachusetts 01854

Worcester Polytechnic Institute

Department of Mechanical Engineering

Worcester, Massachusetts 01609

Michigan. Technical University

Department of Physics

Houghton, Michigan 49331

University of Michigan

Department of Nuclear Engineering

Ann Arbor, Michigan 48109

Mississippi State University Department of Nuclear Engineering

Mississippi State, Mississippi 39762

University of Missouri, Columbia Department of Nuclear Engineering Columbia, Misșouri 65211

University of Missouri, Rolla Department of Nuclear Engineering Rolla, Missouri 65401

New Jersey Institute of Technology Department of Physics \& Engineering Science Newark, New Jersey 07102

University of New Mexico

Department of Chemical \& Nuclear Engineering Albuquerque, New Mexico 87131

Clarkson College of Technology

Engineering Department

Potsdam, New York 13676

Columbia University

Department of Applied Physics \&

Nuclear Engineering

New York, New York 10027 
APPENDIX B-1 (Continued)

Cornell University

Department of Nuclear Science \&

Engineering Programs

Ithaca, New York 14853

Polytechnic Institute of New York Department of Nuclear Engineering Brooklyn, New York 11201

Rennselaer Polytechnic Institute Department of Nuclear Engineering Troy, New York 12181

State University of New York, Buffalo Department of Engineering Science

State University of New York, Maritime College Science Department

New York, New York 10465

North Carolina State University Department of Nuclear Engineering Raleigh, North Carolina 27650

Air Force Institute of Technology Physics Department

Dayton, Ohio 45433

Case Western Reserve University Department of Electrical Engineering \& Applied Physics

Cleveland, Ohio 44106

Ohio State University

Department of Nuclear Engineering

Columbus, Ohio 43210

University of Cincinnati

Department of Chemical \& Nuclear Engineering

Cincinnati, Ohio 45221

University of $0 \mathrm{klahoma}$

Department of Nuclear Engineering

Norman, Oklahoma 73019

Oregon State University Department of Nuclear Engineering Corvallis, Oregon 97331

Carnegie-Mellon University Department of Nuclear Science \& Engineering Pittsburgh, Pennsylvania 15213

Pennsylvania State University Department of Nuclear Engineering University Park, Pennsylvania 16802

University of Pennsylvania

Mechanical Engineering Department Philadelphia, Pennsylvania 19104

University of Puerto Rico

Department of Mechanical \& Nuclear Engineering Mayaguez, Puerto Rico 00708

Tennessee Technological University Department of Engineering Science \& Mechanics Cookeville, Tennessee 38501 


\section{APPENDIX B-1 (Continued)}

ADDRESSES OF INSTITUTIONS IN SURVEY UNIVERSE

WITH ACTIVE PROGRAMS

NUCLEAR ENGINEERING

University of Tennessee

Department of Nuclear Engineering

Knoxville, Tennessee 37916

Texas A\&M University

Department of Nuclear Engineering

College Station, Texas 77843

University of Washington

Department of Nuclear Engineering Seattle, Washington 98195

University of Wisconsin

Department of Nuclear Egnineering

Madison, Wisconsin 53706

University of Texas, Austin

Department of Mechanical Engineering

Austin, Texas 78712

Brigham Young University

Department of Chemical Engineering

Provo, Utah 84602

University of Utah

Department of Mechanical Engineering

Salt Lake City, Utah 84112

Utah State University

Department of Mechanical Engineering

Logan; Utah 84321

University of Virginia

Department of Nuclear Engineering

\& Engineering Physics

Charlottesville, Virginia 22901

Virginia Polytechnic Institute

Nuclear Engineering Department

Blacksburg, Virginia 24061 
APPENDIX B-2

ADDRESSES OF INSTITUTIONS IN SURVEY UNIVERSE

WITH INACTIVE OR DISCONTINUED PROGRAMS

NUCLEAR ENGINEERING

\section{INACTIVE}

California State University

School of Engineering

Northridge, California 91330

San Jose State University

Department of Mechanical Engineering

San Jose, California 95192

Catholic University of America

Department of Mechanical Engineering

Washington, D.C. 20064

Louisiana Technical University

Division of Engineering Research

Ruston, Louisiana 71272

University of Rhode Island

Department of Chemical Engineering

Kingston, Rhode Is land 02881

South Dakota State University

Department of Mechanical Engineering

Brookings, South Dakota 57007

\section{DISCONTINUED}

Hartford Graduate Center

Registrar

Hartford, Connecticut 06120

Memphis State University

Department of Mechanical Engineering

Memphis, Tennessee 38152 


\section{APPENDIX C - SURVEY MATERIALS}

\section{Department of Energy}

Washington, D.C. 20545

September 22, 1978

Dear Professor:

You were recently sent a copy of Nuclear Engineering Enrollments and Degrees, 1977 (DOE/IR-0011), which reported the results of the seventh survey of colleges offering degrees in this field so important to the safe utilization of nuclear power. We are enclosing the forms for recording current (1978) data of the same nature.

Because of growing public awareness regarding the development of nuclear energy, there has been increased interest in reliable data on the supply of well-trained persons in nuclear engineering. Information of this type is of particular interest to policymakers, planners, employers, educators, and students, many of whom have used the results of past surveys.

The survey is being conducted by the Manpower Research Programs unit of Oak Ridge Associated Universities under the sponsorship of the Department of Energy (DOE).

In completing the forms; please include all persons in degree programs who prepare the students to work as nuclear engineers even if the title of the degrees may differ (e.g., mechanical engineering with a nuclear option). A duplicate set of forms for your records and a self-addressed, postage-pald envelope are included for your convenience. We would greatly appreclate recelving your completed questionnaire by October 30, 1978. Please enclose with the questionnaire the latest literature describing your program so that DOE staff can keep current on your program content.

If you have any questions about the questionnaire, please call collect to Dr. Larry Blair, Oak Ridge Associated Universities, (615) 483-8411, extension 371 . 


\title{
APPENDIX C - SURVEY MATERIALS (Continued)
}

2

We appreciate your continuing cooperation in this project and would

be pleased to receive any comments you have on the survey content

or form. Thank you again for your time and interest.

Sincerely,

\author{
Norman Seltzer \\ Deputy Director for Manpower Assessment \\ Division of Labor Affairs and Manpower \\ Assessment
}


APPENDIX C - SURVEY MATERIALS (Continued)

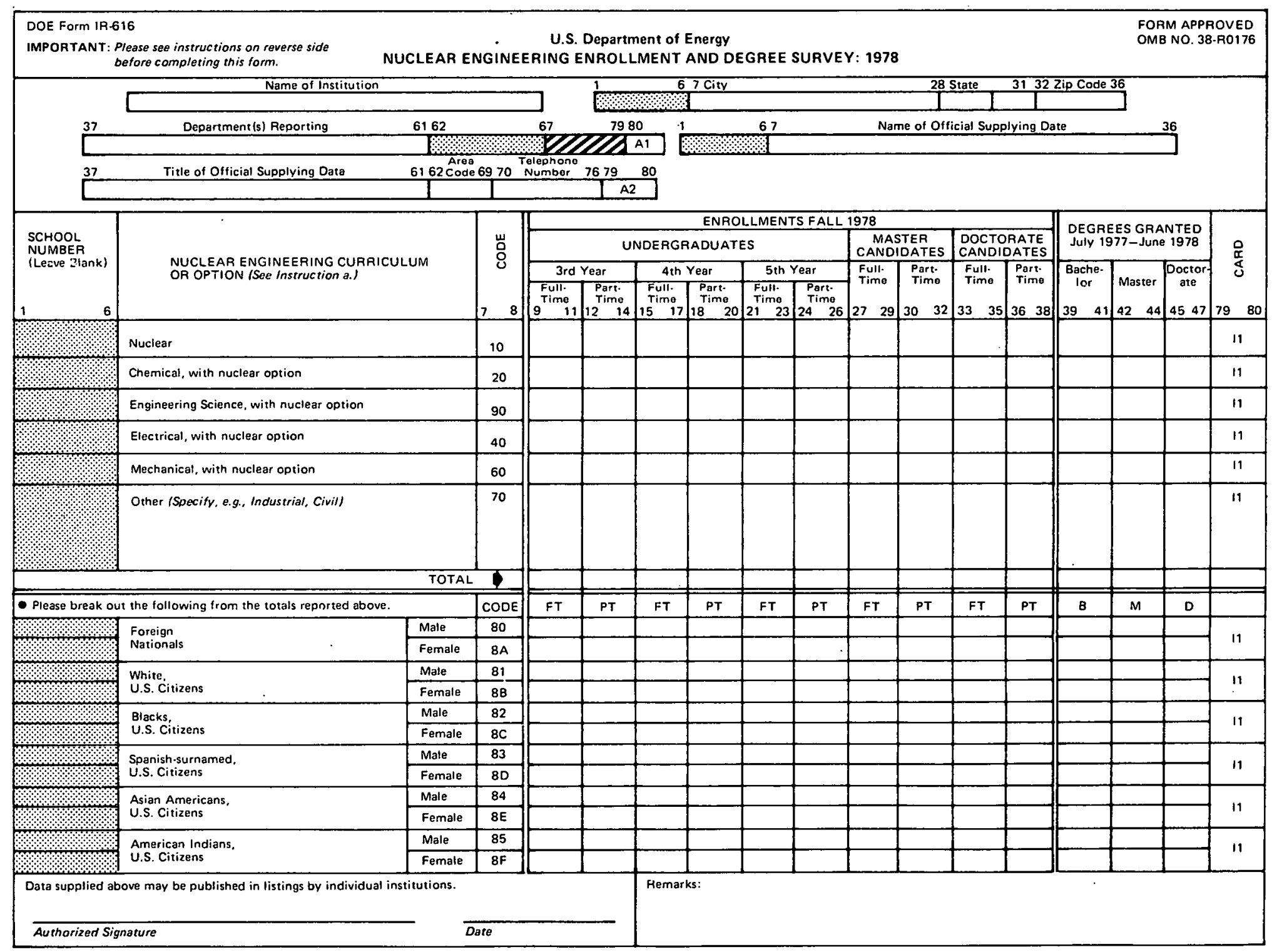





\section{U.S. Department of Energy \\ NUCLEAR ENGINEERING ENROLLMENT AND DEGREE SURVEY-SUPPLEMENT}

Reporting Institution

Date

Please indicate placement or plans of degree recipients for July 1977.June 1978 reported on DOE Form IR-616.

NOTE: "Graduates Returning to previously held jobs" and "Foreign Nationals" should also be included in "Total Graduates."

\begin{tabular}{|c|c|c|c|c|c|c|c|c|c|}
\hline \multirow[b]{2}{*}{$\begin{array}{l}\text { PLACEMENT OR PLANS } \\
\text { AFTER GRADUATION }\end{array}$} & \multicolumn{3}{|c|}{ BACHELORS } & \multicolumn{3}{|c|}{ MASTERS } & \multicolumn{3}{|c|}{ DOCTORATES } \\
\hline & $\begin{array}{c}\text { Total } \\
\text { Graduates }\end{array}$ & $\begin{array}{l}\text { Graduates } \\
\text { Returning to } \\
\text { Previously } \\
\text { Held Jobs }\end{array}$ & $\begin{array}{l}\text { Foreign } \\
\text { Nationals }\end{array}$ & $\begin{array}{l}\text { Total } \\
\text { Graduates }\end{array}$ & $\begin{array}{l}\text { Graduates } \\
\text { Returning to } \\
\text { Previously } \\
\text { Held Jobs }\end{array}$ & $\begin{array}{l}\text { Foreign } \\
\text { Nationals }\end{array}$ & $\begin{array}{c}\text { Total } \\
\text { Graduates }\end{array}$ & $\begin{array}{l}\text { Graduates } \\
\text { Returning to } \\
\text { Previously } \\
\text { Held Jobs }\end{array}$ & $\begin{array}{l}\text { Foreign } \\
\text { Nationals }\end{array}$ \\
\hline Further study & & & & & & & & & \\
\hline $\begin{array}{l}\text { U.S. Academic employment } \\
\text { (show students employec } \\
\text { part time under further } \\
\text { study) }\end{array}$ & & & & & - & & & & \\
\hline $\begin{array}{c}\text { Federal Government } \\
\text { employment }\end{array}$ & & & . & & & & & . & \\
\hline $\begin{array}{l}\text { Government-owned, Contra } \\
\text { tor-operated installations } \\
\text { employment (GOCO's) }\end{array}$ & & & & & & & & & \\
\hline $\begin{array}{l}\text { State and Local } \\
\text { Government employmen }\end{array}$ & & & & & & & & & \\
\hline $\begin{array}{l}\text { Industrial employment } \\
\text { within U.S. }\end{array}$ & & & & & & . & & & \\
\hline $\begin{array}{l}\text { Employment with foreign } \\
\text { employer }\end{array}$ & & & & & & & & & \\
\hline U.S. Military service & & & & & & & & & \\
\hline Other (specify) & & & & & & & & & \\
\hline Still seeking employment & & & & & & & & & \\
\hline Unknown & & & & & & & & & \\
\hline
\end{tabular}

